\section{EMBRYARIDDLE}

Aeronautical University

SCHOLARLY COMMONS
Journal of Aviation/Aerospace

Education \& Research

Volume 18

Number 1 JAAER Fall 2008

Article 6

Fall 2008

\title{
Learning Theoretical Concepts through Community Problem Solving: Service-Learning in Flight Safety Courses
}

Antonio I. Cortes

Follow this and additional works at: https://commons.erau.edu/jaaer

\section{Scholarly Commons Citation}

Cortes, A. I. (2008). Learning Theoretical Concepts through Community Problem Solving: Service-Learning in Flight Safety Courses. Journal of Aviation/Aerospace Education \& Research, 18(1). https://doi.org/ 10.15394/jaaer.2008.1390

This Article is brought to you for free and open access by the Journals at Scholarly Commons. It has been accepted for inclusion in Journal of Aviation/Aerospace Education \& Research by an authorized administrator of Scholarly Commons. For more information, please contact commons@erau.edu. 


\title{
LEARNING THEORETICAL CONCEPTS THROUGH COMMUNITY PROBLEM SOLVING: SERVICE-LEARNING IN FLIGHT SAFETY COURSES
}

\author{
Antonio I. Cortés
}

\begin{abstract}
Critics of higher education often criticize the chasm separating esoteric academic theory from the pragmatic knowledge required of students after graduation. Service-learning is presented as a catalyst for intrinsically motivating students to master course concepts. In service-learning, students collaborate with each other and with external stakeholders to fuse classroom theory with practical application in order to address real-world problems. Typological and historical overviews of service-learning are provided with special emphasis on how the systemic incorporation of service-learning throughout a degree program may increase student persistence by harmonizing academic processes with generational values. The use of service-learning in flight safety courses at Embry-Riddle Aeronautical University has not only improved safety at the campus and in the surrounding aviation community, it has enhanced the learning of technical concepts in students while greatly improving their soft skills.
\end{abstract}

When Mark Twain sardonically boasted that he never let his schooling interfere with his education, one can be rather certain that he was not referring to the need for servicelearning in higher education curricula, but rather lamenting how formal education often falls woefully short of imparting practical knowledge to its learners. Twain's prescient musing highlights the often cited distinction between the act of teaching and the process of learning. Professors often pride themselves in their lecturing skills, but must stop to consider the disturbing truth that only active learning can truly tap the full potential of the education process. The correlation between teaching and learning is particularly relevant for university administrators who recognize that classroom learning processes have a direct impact on student persistence.

It is rather self-evident to state that students who enjoy education will have a tendency to remain in school and will result in the pursuit of excellence after graduation. Pundits are quick to criticize such assertions as promoting edutainment instead of meaningful instruction. Educational psychologists counter by proclaiming, "Making learning fun is serious business." How can enjoyable learning be induced without sacrificing the necessary rigors of a curriculum and without sliding to the lower hierarchies of cognition in Bloom's Taxonomy? Over the past few decades a highly enjoyable yet challenging learning catalyst has been implemented at many universities that attempts to fuse academic theory with the pragmatic appeal of real-life applications. By utilizing the theory exposed in a university course to address community problems, students simultaneously serve society while using active learning to master academic concepts.

Since institutions of higher learning serve as centralized repositories of human capital for society, it stands to reason that local communities should benefit directly by each university's presence amongst them. Service-learning attempts to link academic processes with societal needs in a symbiotic arrangement that polishes the reputation of the host institution, benefits the members of society by providing free intellectual capital, and provides learning dividends for students tasked with addressing the community problems.

Although service-learning has penetrated into the mainstream of liberal arts curricula with great success, it has not seen widespread acceptance within the technical disciplines of the academy. Many educators in the hard sciences erroneous perceive that service-learning falls outside the functionality of their learning processes and thus miss a stellar opportunity to simultaneously improve the technical and soft skills of their students. One such field that has notoriously escaped the attention of service-learning is aeronautical science. Over the past few years, service- 
learning has been applied experimentally in flight safety courses under the aeronautical science curriculum at EmbryRiddle Aeronautical University (ERAU) in Daytona Beach, Florida. The result has shown that service-learning can adroitly be used to produce a transformative academic experience for students.

\section{LEARNING SHOULD BE TRANSFORMATIVE}

The utopian perspective on academic processes holds that student learning should be a transformative event. At one extreme of the spectrum of possible transformation, moving a person to doubt previously accepted concepts can shake their foundational knowledge and cause them to see the world in completely new ways. At the modest end of the transformation gamut, the student can hopefully gain a new perspective on an issue that was previously missed and learn to apply the new knowledge for tackling the common demands of the workplace after graduation. Unfortunately, education is rarely transformative and often resides in the comfortable but useless corner of mediocrity that sees knowledge treated as discrete bundles of information that are broadcast from behind a pulpit to a passive audience bereft of motivation to receive it. Even attempting to present and evaluate course material at the highest levels of Bloom's Taxonomy is no guarantee that the student will be transformed. As alluded to in a recent publication, "One major challenge for undergraduate education is to create intellectually engaging contexts for learning that vest students in their learning, expanding intellectual curiosity, and foster intellectual development throughout the undergraduate years" (Evenbeck \& Hamilton, 2006, p.17).

When assessing such a quote and recognizing the call for transformative action, it proves rather dismaying to read the data compiled by the National Center for Education Statistics, which states that $83 \%$ of all higher education faculty use lecturing as the primary instructional method (Chen, 1998). Proponents of education reform have long touted the benefits of active learning in the classroom. Essentially, active learning entails any student engagement in course material through means other than listening. It has been proven repeatedly that writing, speaking, deep thinking, and especially demonstration, all serve to imprint knowledge far more effectively than merely listening. In the aviation world, novice flight instructors are often told that their newly minted certificate may allow them to teach professionally, but also serves as a passport to in-depth learning. The allusion being made is certainly a reference to active learning, since the instructor will learn a given subject deeply by the act of lucidly conveying it to someone else versus by merely having access to the information in his or her memory.

Experience gained by performing an action is thus seen as the optimal path to learning. Perhaps that is why the British novelist C.S. Lewis was fond of saying that experience was the most brutal of teachers, "but you learn, my God do you learn." Albert Einstein was once quoted as calling experience the only source of knowledge. Since actively investing one's intellect in an experience provides the greatest opportunity for transformative learning, one can start to see the appeal that service-learning has as a vehicle for providing students with experience within the guidance of a preset curriculum.

\section{WHAT IS SERVICE-LEARNING?}

As can be imagined, reaching consensus amongst K-16 educators as to the definition and typology of a new academic initiative endowed with myriad implementation methodologies can be daunting. Nevertheless, through the work of several organizations and a few key scholars, general agreement as to the makeup of service and learning endeavors was achieved during the 1990s. As a starting point, service-learning must be differentiated from the wider term of experiential education by the fact that servicelearning relies on a community of stakeholders external to the school as the recipient of student action meant to assuage an existing problem. The degree to which the student or community is the focus of the educational effort can be further examined through a typological analysis.

\section{Service and Learning Typology}

Depending on the objectives of a curriculum, an academic endeavor seeking to produce a learning bridge between students and their community may choose to stress learning goals, service goals, strive to reach a balance between both, or hold both goals completely independent. In the 1990s, Robert Sigmon developed a way to depict the typology of service and learning by using hyphenation and capitalization to connote distinctions depicting where the emphasis lies between the service performed and the learning achieved by students, as illustrated in Figure 1. 


\begin{tabular}{|ll|}
\hline SERVICE - LEARNING & $\begin{array}{l}\text { Both aspects equally stressed in process } \\
\text { Learning value of process prioritized over service } \\
\text { Service - LEARNING }\end{array}$ \\
performed to community \\
SERVICE - Learning & $\begin{array}{l}\text { Service performed to community prioritized over } \\
\text { learning value of process }\end{array}$ \\
Service Learning & $\begin{array}{l}\text { Each component of process treated as independent of } \\
\text { each other }\end{array}$ \\
\hline
\end{tabular}

Figure 1. The commonly accepted typology of service and learning used to discern where the emphasis of an educational effort lies through the use of hyphenation and capitalization (Naughton, 2000).

For purposes of this paper, the use of "service-learning" as a hyphenated term is not fortuitous, but is a deliberate attempt to discuss an educational initiative where student learning and community service are given equal attention. In other words, the term "service-learning" applies when projects are structured to give equal emphasis to the learning produced by students and to the benefits engendered for the recipient community. In some cases, professors may use student action in the community merely as an illustrative example of the concepts covered in class. Such an approach would exemplify the "service-LEARNING" typology. Similarly, it can be envisioned that projects instigated by the university in response to requests made by the community may result in "SERVICE-learning" orientations.

\section{Definitions of Service-Learning}

Over the past decades, numerous scholars have attempted to define the concept of service learning. The typological distinctions previously analyzed poignantly showcase the difficulty in achieving consensus on a single definition for learning involving community service. As a result, many educators have produced definitions germane to the specific construct of their own initiatives. Such a caveat notwithstanding, several areas of consensus seem to have emerged within the academic community. Service-learning and related variations, as denoted by alternate typologies through hyphenation and capitalization, must involve an educational experience for academic credit where students participate in structured activities tied to curricular objectives and which satisfy some community need (Muthiah, 2003).

Alternative definitions of service-learning tend to distinguish whether operational control of a given project resides with community stakeholders, with the students, or with the sponsoring professor. Likewise, some argue that service-learning only reaches its educational purpose when performed in parallel with continuous and summative reflection by participating students. For example, one proffered definition describes service-learning as, "A teaching method where guided or classroom learning is deepened through service to others in a process that provides structured time for reflection on the service experience and demonstration of the skills and knowledge acquired" (Kaye, 2004 , p. 7). Other perspectives highlight the long-term learning of civic mindedness in students as the overriding purpose; no doubt as a function of the discipline within which the service learning project falls (Champagne, 2006).

\section{Benefits to all Three Stakeholders}

One aspect of service-learning seems to have reached universal acceptance. Educational projects that involve students with the community have the potential to benefit three key stakeholders: the students, the community, and the sponsoring university. The students benefit by being able to bridge the gap, often quite cavernous in nature, between the Ivory Tower and the real world. Instead of becoming lost in abstract and esoteric theory in the classroom, students can vividly recognize the application of course concepts and must do so lest they earn the disdain of community members not pleased with the service that is being provided. The community stakeholders, as the recipients of the students' efforts, benefit by having energetic workers endeavor to fix or, at the minimum, address a pressing issue that has hitherto gone untended. Lastly, the sponsoring university gains recognition as a repository of intellectual capital and as a solution-provider in the community. Such a distinction bodes well for the creation of alternative revenue streams through town-gown business partnerships and for lucrative capital endowment campaigns pursued with philanthropists affiliated with the university and with business leaders in the local community.

\section{Service-Learning Processes}

In order to ensure that all three stakeholder interests are justly represented in a service-learning curriculum, 
professors must effectively design the construct of projects. The first planning step requires identification of a need within the community that does not contradict the ethos of the university. Then, the professor must connect the determined need to a given academic curriculum so that it best reinforces and expounds on the core concepts of a course. Next, the nature of the project must be designed so as to create action within the community while remaining within the temporal boundaries of the course. Finally, the project must have a culminating phase marked by student reflection on the work that has been accomplished (Kaye, 2004). Often times, written journals and team presentations can be used as methods for prompting reflection and sharing the experiences of the project with other members in the course.

The commonly accepted outcomes of service-learning for students include enhanced learning of academic concepts, the use of personal skills to benefit the community, attempting to address real problems, individual growth, enhanced respect for one's classmates, improved citizenship, the chance to feel successful at an endeavor regardless of one's starting skills, a deepened awareness of self and others, and practice using teamwork skills for problem-solving (Kaye, 2004).

Some liberal arts professors stress the opportunity that service-learning provides for promoting civic responsibility and political activism in community affairs. Business educators often tout benefits of wrangling with real ethical decision making in the context of social responsibility. Regardless on the different perspectives which abound, most educators agree that service-learning provides a marked improvement over feeble lectures that solely tap passive learning processes in students. In fact, service-learning fuses community work with academic concepts in synergistic fashion so as to form a new type of integrated model for education (Howard, 1998).

Service-learning as a version of problem-based learning

In many ways, service-learning is similar to problembased learning in that they both entail the experience of strong emotions, initial moments of denial, then a resistance against solving the issue at hand by some students, only to give way and eventually produce a sense of focus (Woods, 1994). Problem-based learning is simply an umbrella term for any academic process that involves teaching through a specific problem (Henley, 2003).

Additionally, service-learning projects present students with intricate, often ambiguously defined challenges where all resources must be brought to bear to define the problem accurately and, ultimately, to create a workable solution. Students must develop and test hypotheses, determine what new knowledge must be gained to solve the problem, then coordinate team processes and delegate work in order to achieve their goals (Barrows, 1988).

Service-learning students also see the benefit of motivation by witnessing its effect on how quickly and effectively their tasks are accomplished. They must practice self-direction in the learning and application of skills, unwittingly integrating interdisciplinary knowledge to solve a given problem following methods that foreshadow how they will work professionally after graduation. Throughout the process, each team member will share opinions of how critically each peer has reasoned through their aspect of the problem (Barrows, 1996, \& Henley, 2003). Such intellectual collaboration and peer learning processes are priceless and provide a measure of performance deemed more relevant to students than any feedback a professor may provide.

The methodology behind problem-based learning, shown in Figure 2, is analogous to the methods employed by service-learning. Both types of learning commence by outlining the specific objectives and methodology via a controlling document, such as a course syllabus. Next, material in the form of coursework, reading, or research, is required in order for the student to integrate myriad concepts and prepare to apply them. Then, the trigger for the project is provided, such as the community problem to be addressed in the service-learning version of the model. At that point, the student teams collaborate to accurately define the problem, craft alternatives, attempt to solve the problem, and then assess how well their solution worked. 


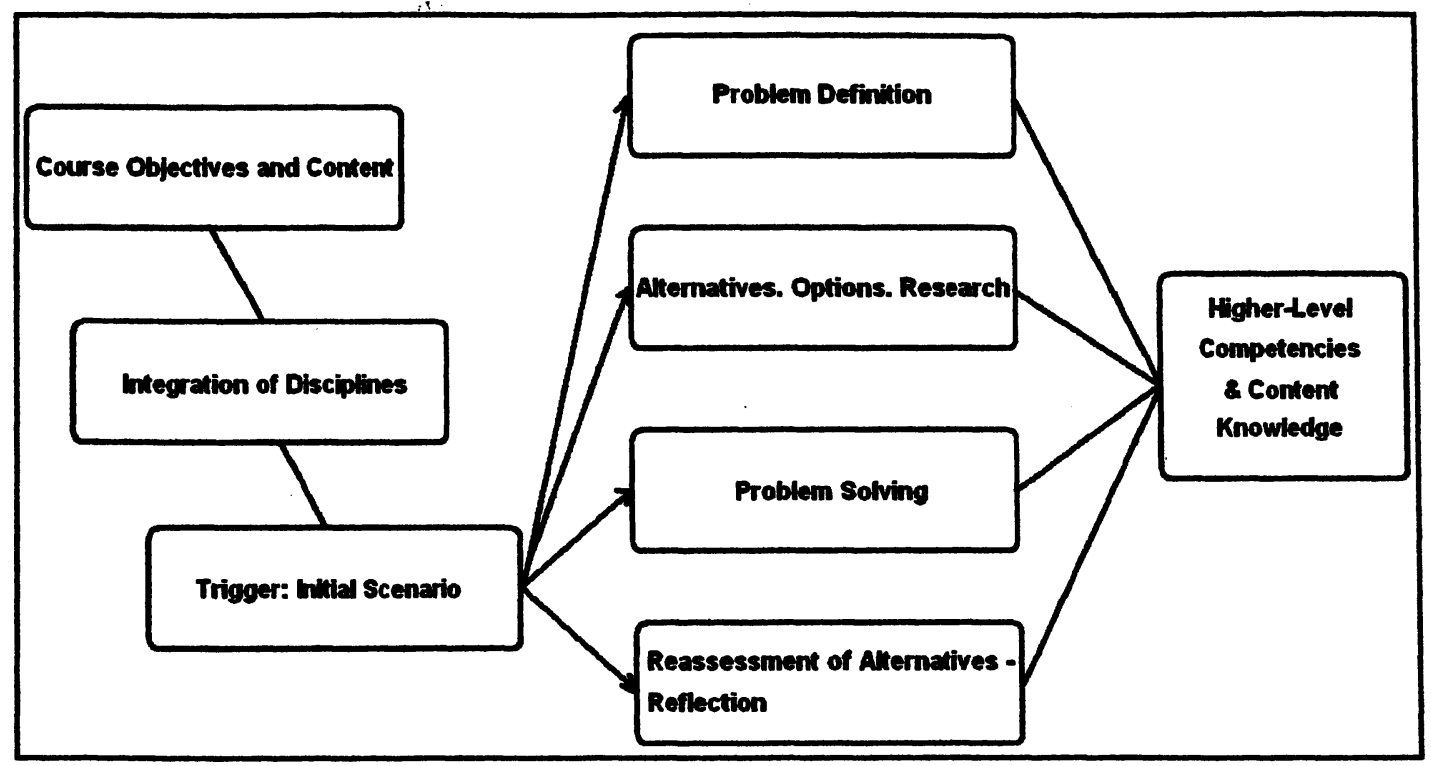

Figure 2. Scenario development for problem-based learning utilizes the same construct as service-learning (Henley, 2003).

The result of the entire endeavor is the creation of competency in the course material at a far deeper level that could have been achieved through other educational methods. Furthermore, the content of the course is presumably learned more holistically and is stored at a deeper level for future application.

\section{THE HISTORY OF SERVICE-LEARNING}

Although many educators view service-learning as a relatively new initiative within the academy, the spirit of service-learning has pervaded higher education in one form or another since the first universities were established. When one ponders the genesis of higher education and the reasons for it in society, it is tempting to see universities as somewhat of a commodity for the creation of expertise to fuel the gears of advancement and industry. In other words, some may perceive the role of universities and colleges in society as being analogous to the role of factories, producing trained and civil workers for needy companies. From such a materialistic perspective, it makes perfect sense to create internships and other learning opportunities as methods for accustoming students to the rigors that will follow graduation.

\section{Universities as Service Providers}

In a more altruistic sense, universities are repositories of expertise and function to serve society not merely by producing trained workers, but by lending insights into daunting problems that seem impervious to simplistic fixes. Since the earliest universities were established, such as the 
University of Al Karaouine in Morocco, founded in 859, and Al-Azhar University in Egypt, founded in 988, universities have been providers of solutions for society. In 1913, the President of the University of North Carolina, Edward Kidder Graham, heartily encouraged North Carolinians to submit their everyday problems to the university for solving (Dibbert, 2006). Graham saw the university as a locus of talent and thought it was the university's obligation to attempt to fix the most vexing problems in the surrounding community. The university stood to gain from the process by enhancing its reputation for scholarship and by helping professors avoiding dealing only in abstract concepts bereft of applications for the citizenry. The difference with servicelearning today, as opposed to the attempts by the academy to provide fixes for societal ills in the past, is that the solutions engendered through service-learning programs are designed by students instead of faculty.

\section{Roots of service-learning in the 1930s}

The philosophy of service-learning has evolved over the past few centuries and today sees widespread use in primary, secondary, and tertiary education. Towards the dawn of the $20^{\text {th }}$ Century, the greatly influential philosopher, John Dewey, believed that experience was a pivotal component of learning and advocated linking the knowledge imparted in school to the needs of surrounding communities (Muthiah, 2003). While at the University of Michigan, Dewey advocated mixing practical experience and education in his 1933 and 1938 works, "How We Think," and "Experience and Education," respectively (Eyler \& Giles, 1999). Slow progress in developing experiential learning ensued over the next few decades, but saw a rebirth in the tempestuous 1960s.

\section{Major development in the 1960s}

A commonly accepted form of service-learning that became popular in the 1960s is internships, where students work in corporate settings to gain experience in certain fields while companies benefit by having the opportunity to assess the student's skills for possible future employment. It was during that time period that the term "servicelearning" saw its introduction as meaning the pursuit of work that fills a need and which also educates. The term is attributed to the Southern Regional Education Board and also to the work of educators Robert Sigmon and William Ramsey.

In concert with the emergence of service-learning, the incorporation of problem-based instruction into medical school curricula began with aims to enhance the preparation of students for clinical practice (Barrows, 1996). As previously mentioned, in much the same way that servicelearning can be seen as a subset of the experiential learning movement, many of the processes contained within problem-based learning are analogous to those in servicelearning. To clarify and differentiate amongst the emerging academic initiatives, the Atlanta Service-Learning
Conference in 1969 made the first formal attempt to define the link between schools and communities (Muthiah, 2003; Eyler \& Giles, 1999).

\section{Growth fueled by volunteer spirit in 1980 s}

Decades later in the 1980s, a combination of volunteer spirit within society and an outright push by educational scholars attempting to promote active learning processes combined to see service-learning accelerate in acceptance as a way to fulfill both volunteerism and active learning (Muthiah, 2003). The Council for Adult and Experiential Learning and the National Society for Experiential Education started promoting the use of service-learning as a curriculum enhancer. In 1983 the National Youth Leadership Council was chartered and promoted "towngown" relationships as a way to provide purposeful education for K-16 students while benefiting surrounding communities (Eyler \& Giles, 1999). In 1984, students in higher education created the Campus Outreach Opportunity League to encourage student engagement in service as a national resource. The next year, presidents of several institutions of higher learning founded the National Center for Campus Contact in order to enhance the role of community service within academe (Weigert, 1998). To this day, the Center holds annual service-learning conferences to promote what it calls "episodic experience" for students as a way to affect long-term behavior and to foster civic service (Eyler \& Giles, 1999).

\section{Mainstream acceptance during $1990 \mathrm{~s}$}

The momentum gained by the service-learning movement during the student activism of the 1980s sewed the seeds for mainstream acceptance during the subsequent decade. In 1992, Maryland high schools were the first to require student participation in service-learning as a prerequisite for graduation. Two years later, the Michigan Journal for Community Service-Learning was launched as the first refereed service-learning journal (Titlebaum, Williamson, Daprano, Baer, \& Brahler, 2004). As testimony to the ardent adoption of service-learning by some institutions during the 1990s, it should be noted that over 160 courses and more than 3,300 students were involved in service-learning at Indiana University Bloomington in the 1998-1999 academic year (Conley, 2000).

\section{Service-learning today}

The implementation of service-learning curricula continues to increase at institutions of higher education across the nation. Over 950 colleges and universities have touted their commitment to town-gown relationships and tens of thousands of faculty are engaged in service-learning at any given point with literally millions of tertiary education students (Butin, 2006). Just last year, the president of the University of Georgia used a state of the university address to announce that service-learning would comprise one of six key processes for creating a culture of academic rigor at the institution (Wilder, 2006). 


\section{APPEAL OF SERVICE-LEARNING TO THE} MILLENIAL GENERATION

As the history of service-learning is reviewed, one cannot help but notice how the movement appears to be gaining momentum. Is the increased evidence of service-learning curricula strictly due to enhanced awareness of its benefits by educators, or is there another reason that lies outside of the academy's direct control? It is proffered that the success of any educational initiative is partly engendered by how well it mirrors the values held by students. For the most part, such values are the result of the social context that framed the upbringing of each student, as explained by generation theory. Professors with ossified teaching practices who are impervious to the morphing values of each progressive generation of students passing through their classrooms suffer from a massive blind spot in their pedagogy. Such professors are unwittingly missing significant opportunities to create learning by custom-tailoring their initiatives to their audiences.

In the business world, far removed from academe on some levels yet eerily similar in its customer-centric constructs, the thought of delivering a service without intimate knowledge of the intended market segment is tantamount to revenue suicide. Yet in academe, the inflexibility of curricula and teaching methods, vis-à-vis the changing values of students, is a perfect example of stubborn reluctance to accept the fact that the students in our classrooms change with each passing decade. Generation theory argues that people are shaped by the cultural trends and history that engenders their upbringing, prompting tangible changes in the personae, attitudes, values and beliefs of people every so often.

\section{Generation Theory for Educators}

As applied to the changes in human value systems prompted by societal context, generation theory studies "series of birth cohorts who share a common location in history and a common peer persona that reflects their collective identity as well as a sense of having shared experiences" (Magolda \& Kelsey, 2006). Although each generation is approximately 20 years in length, the impact of the surrounding social movements on each generation occurs over a 10-year period and fosters perceptions and values into children from 10 to 18 years of age (Magolda \& Kelsey, 2006).

\section{Millennial Student Characteristics}

Virtually all traditional undergraduate students at colleges and universities at the start of the $21^{\text {st }}$ Century were born after 1982 and comprise what is known as the Millennial Generation. No end date has yet been established to determine a cutoff for the current generation, but judging from past generational timelines, it will most likely finish with people born around the turn of the Millennium; hence the label used to define the generation. Although this group of students was originally labeled Generation $Y$ an allusion to their status following Generation $\mathrm{X}$, most generation scholars seem to prefer the millennial moniker over the past few years to avoid implying that one generation is merely an offshoot of the previous.

Millennials comprise over $\mathbf{1 0 0}$ million members and are characterized as valuing civic responsibility, community service, and helping others. Millennials are described as being optimistic and feel that they can make a positive contribution to their world (Magolda \& Kelsey, 2006). These qualities, like any pursuant to the study of generation theory, are sweeping generalizations that may not apply to each individual Millennial. Nevertheless, as a whole, the stated characteristics prove rather accurate in depicting the ethos and internal drive of the population born after 1982. Service-Learning is perfectly suited for Millennials

The internal drive within typical Millennials that compels them to better the world is auspiciously suited for servicelearning projects within academe. The nature of servicelearning as a means of improving communities perfectly mirrors the altruistic streak inherent in Millennials. Specifically, a recent National Survey of Student Engagement revealed that today's undergraduate student desires courses that include participation in community projects and actively seek internships and opportunities for volunteering in community service (Magolda \& Kelsey, 2006).

Another recent work endeavored to determine the top trends in youth culture as a means of framing the current generation. The fourth ranked trend was determined to be student activism and the seventh ranked trend established that group work is seen as the norm by Millennials. The study brought to light that students today feel empowered as agents of social change; possibly as an attempt to oppose the stereotypically jaded members of Generation X, who had their teenage years impacted by the 1980s and who are increasingly the parents of Millennials (Haynes, 2006). Also of noted difference from previous generations, students today have been brought up in an environment that imbued them with the synergistic value of group processes and which results in a tendency to favor team work and collaborative methods for accomplishing tasks (Howe \& Strauss, 2000).

During an anonymous survey conducted of Millennial students taking three upper-class courses at ERAU, the overwhelming majority voiced their preference for collaborative learning processes instead of traditional academic lectures. Figure 3 showcases the breakdown in student survey answers when asked the question, "Do you prefer collaborative learning processes or the traditional lecture style for covering course material." 


\begin{tabular}{|l|c|c|c|}
\hline \multicolumn{1}{|c|}{ Course } & Number of students polled & $\begin{array}{c}\text { Prefer some collaborative } \\
\text { learning }\end{array}$ & $\begin{array}{c}\text { Prefer } \\
\text { only Lecture }\end{array}$ \\
\hline Airline Operations & 30 & $83 \%$ & $17 \%$ \\
\hline Flight Technique Analysis & 23 & $91 \%$ & $9 \%$ \\
\hline Flight Safety & 15 & $86 \%$ & $13 \%$ \\
\hline
\end{tabular}

Figure 3. Millennial students prefer team settings for learning material, as shown in this anonymous survey conducted at ERAU in October of 2006.

The student survey, although rather limited in scope, produced results which clearly support the assertion that today's undergraduate students prefer team processes over lecture methods. Anecdotally speaking, students do seem to possess a tangible preference for working in groups, as shown in Figure 4, as observed in numerous undergraduate classes over the past few years. The implication that can be drawn for such a preference is that students will quickly incorporate into groups created during service-learning projects and will have a tendency to view group work as a natural precondition for accomplishing the assigned community tasks. When the inner drive to change the world is coupled with the inclination for group work, it seems only natural that professors utilize this generational tendency through team-based service-learning projects.

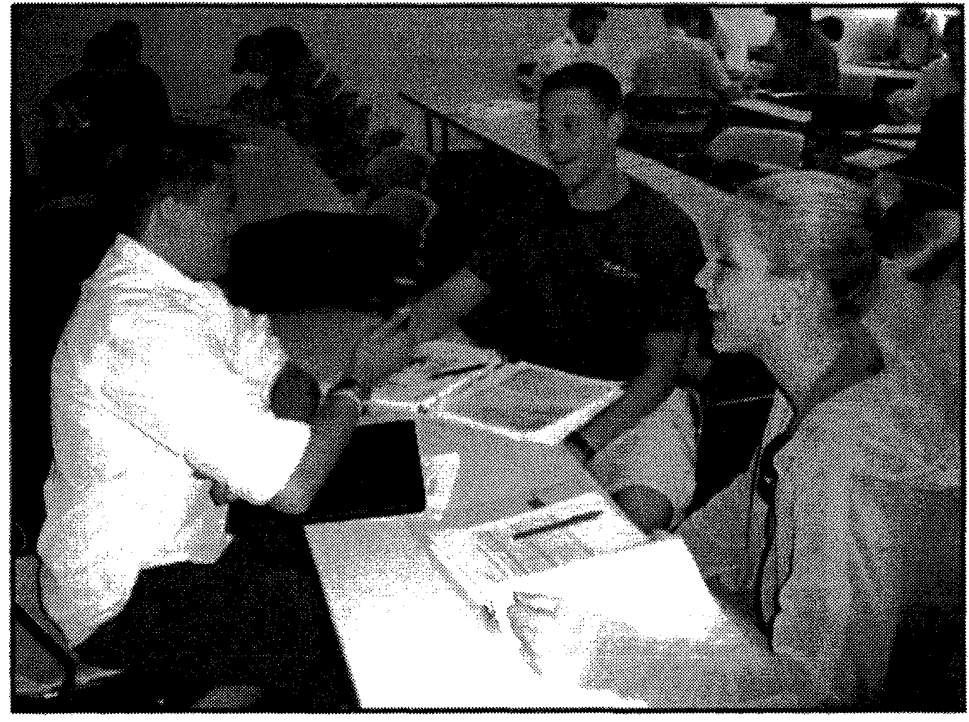

Figure 4. Millennial students enthusiastically collaborate in the planning of a service-learning project at ERAU. 


\section{RESULTS OF SERVICE-LEARNING'S ADOPTION BY ACADEME}

It is tempting to rely on one's intuition and conclude that service-learning's adoption as an academic process has been successful. After all, with increasing numbers of universities instigating service-learning curriculums and individual professors incorporating service-learning to their courses, it stands to reason that certain gains must be evident. The value provided to students by service-learning is two-fold: not only does it teach the concepts of a course deeper by the very fact that active learning processes form the core of service-learning, but the group nature of projects pursued also create secondary benefits for each student's intellectual development.

The purported learning enhancement obtained by tying community service with course curricula is a result of the mental processes that service-learning requires. Using real life problems as constructs for learning core concepts in a course results in the deep storage of the material in the student's long term memory. In addition to learning the primary objectives of a given curriculum, each student participating in service-learning also develops soft skills such as an awareness of team dynamics and communication acumen.

\section{A Catalyst for Purposeful Learning}

As determined by Eyler \& Giles in 1999, the four primary benefits of service-learning, as self-reported by students themselves, are and increase in learning and in motivation to work hard, a deeper understanding of the material and concomitant readiness to apply knowledge, a perception that the learning obtained was more interesting and challenging than that which results from conventional processes, and an increase in the realism and complexity of the analytical and causal cognitive models used to grasp the subject matter. The benefits of service-learning have also been summarized as the reconnecting of theoretical concepts to practice (Becket \& Grant, 2003). As stated by the students themselves, the primary gains seem to occur in a deeper understanding in the material and in possible applications of their newly gained knowledge to real-world circumstances. In one study, many students alluded to the vastly enhanced amount of learning they had obtained through service-learning, sometimes making the stunning statement that they had learned more during one single service-learning course than during their entire college experience (Elyer \& Giles, 1999).

\section{Internal locus of control}

From the perspective of educational psychology, servicelearning is considered an effective catalyst for learning course concepts because an internal locus of control is created within participating students that capitalizes on the emotional process of personalized learning. At its heart, a service-learning project is an attempt to solve a real problem with living stakeholders. The process is thus viewed as a subset of problem-based learning where students are empowered with a powerful combination of intellectual autonomy and solution ownership. In fact, for properly devised service-learning projects, the psychological processes intrinsic to their accomplishment operate at certain andragogical levels.

The inherent unpredictability of student-centered learning requires the continuous reassessment and restatement of goals by students attempting to solve a problem. Students in such situations must constantly reassess objectives as new information is received. This action requires that students inventory the skills provided via their course and assess how and best to apply them in real life scenarios (Tennant, 1997). An internal locus of control is further encouraged by working in a team setting where collaboration is required to solve common problems and to accomplish predetermined goals. In so doing, students see how their behavior and those of their peers influences outcomes and they begin to learn just how much effect their own actions have in controlling both the success of the service-learning project and the grade they receive for their efforts (Bean \& Eaton, 2001).

The psychological concept of locus of control was developed by Julian Rotter in the 1950s. The basic premise of the concept entails the human tendency to perceive chances of favorable future outcomes as a function of causes that are either within their control or subject to external factors. Those individuals with an internal locus of control view necessitated actions as being within the limits of their human capacity (Ormrod, 2004). For example, many student advisors will lament the prevalent tendency of students to forecast mediocre academic performance in a given class due to the ineffective teaching style of their professor; thus denoting a perceived external locus of control. A great amount of time is spent by academic advisors attempting to foster an internal locus of control for academic performance amongst their advisees by convincing the students that they hold the key to their grades. Astute advisors will provide proven and flexible methods for improving student grades, such as enhancing studying processes and the amount of time dedicated to assignments.

An internal locus of control plays a pivotal role in creating intrinsic motivation for mastering the course concepts (Theall, 1999). If the project being undertaken 
bears even a remote resemblance to the problems expected to be faced in a student's professional future, the perceived relevance of the material being learned obviously rises. As a result of the perceived relevance, students tend to construct a cognitive depiction of the requirements for completing the project and of the concomitant knowledge and skill areas that they must obtain as part of the solution.

\section{Learning becomes personalized}

In keeping with the previously mentioned similarities to andragogical principles, service projects also create very personal learning by virtue that it becomes customized to fit each student's abilities. Any given class showcases students who exhibit the full spectrum of learning speeds and styles. Traditional lectures treat students in a class as a homogenous learning group, whereas service-learning allows each student to research only the background information about a topic that they are unfamiliar with in order to accomplish the project at hand. Furthermore, each student involved in service-learning can build their necessary knowledge base at their own speed and in the way which best suits them.

Learning is also personalized to each student, since connections are created with other people involved in the project; both with teammates and with the community stakeholders who depend on the outcome of the project. Often termed constructive engagement, the interaction with dynamic players, each with personal agendas and hopes, serves to personalize the learning involved (Eyler \& Giles, 1999). Furthermore, the real-world nature of the project personalizes the learning process itself, encouraging students to take a keen interest in the outcome and prodding them to ensure that such an outcome is acceptable to all stakeholders (Pietersen, 2002). As described by Eyler \& Giles, "One of the facets of service-learning classes that excite students is the quality of the interpersonal experiences that occur in the community compared with their usual classroom work. We have been continuously struck by the way in which the emotional power of service-learning helps students connect intellectually with what we are doing in the classroom" (1999, p. 23).

\section{Constructivism as an underlying process}

Augmenting the positive effect of personalized learning is the fact that service-learning exemplifies the recent push for constructivism in academic learning. Traditionally, positivism has pervaded educational practices, offering an inflexible view of knowledge as a finite parcel of information that can be transmitted from teacher to student. Today, many educational psychologists espouse a belief known as constructivism, which explains learning as an active function within a social context (Hughes, 2002). A service-learning project uses constructivism as a philosophical foundation, recognizing that knowledge is best internalized when adjusted for use by each student to solve a challenge. In so doing, the knowledge is encoded to fit a student's personal model of how the world works (Hughes, 2002).

\section{Primary Learning Achieved}

Skeptics sometimes voice the belief that service-learning benefits the community surrounding a university with free labor and provides sponsoring universities with free goodwill at the expense of its students. In reality, the design of the service-learning project, as determined by the university's curriculum or by the sponsoring professor, will completely dictate the percentage breakdown of benefit afforded to students versus to the community; as previously depicted in the discussion on typology. It falls well within the operational control of the service-learning curriculum to make students the primary beneficiaries of service-learning by stressing the mastery of theory through practical application.

It proves curious to contemplate the extent to which a traditional lecture course teaches concepts and passes knowledge to its students. To make such discernment, one must distinguish amongst the many levels of learning that can occur. Has the material been learned at the lower or upper cognitive levels of Bloom's Taxonomy? A year from now, how much of the information learned will the student be able to recall and, even more to the point, how much of the knowledge will the student be able to apply to problems being faced?

\section{Increased depth of learning}

Some critics of the teaching processes in higher education are quick to point out that students often have a false sense of confidence that they know material; whereas in reality, may only possess the most rudimentary understanding of the course concepts. A leading authority on human error, Dr. Tony Kern, offers insight on human nature by humorously, but poignantly, defining confidence as "that which is produced moments before you understand the problem." Kern's allusion highlights how challenging it is to detect one's own blind spots when learning material in an academic setting. One of the significant benefits stemming from service-learning is how it fosters active learning opportunities for students to probe the depths of their knowledge to see whether it suffices for tackling real-world problems to the satisfaction of external stakeholders. A student can believe that the material presented in class has been mastered, as feebly evidenced by high scores on 
classroom assessments, only to recognize how much profundity of knowledge was missed when confronted with applying the knowledge to a real life problem.

Such thoughts are reminiscent of Voltaire's philosophical musings, which include the assertion, "Judge a man's contributions by the questions he asks, not by the answers he provides." Whereas traditional classroom assessments require students to answer questions, service-learning promotes a Voltairean approach to gaining knowledge, where students must formulate their own questions for solving a problem, then produce effective ways to address the questions.

The inescapable fact is that, "Traditional lecture formats follow the 'pedagogical' teaching model in that they are teacher-centered, and not necessarily influenced by the needs or interests of the students" (Brady, Stolzer, Muller, \& Schaum, 2001, p. 33). The primary value of servicelearning, here perceived as the antithesis of lecture, is that it connects the curriculum with the concern and caring of Millennial students, producing "memorable, lifelong lessons" for them (Kaye, 2004, p. 6). The intent, then, is for students to store the material being conveyed through a course in deep storage, versus just remembering the concepts temporarily with no motivation for future recall after the final exam of a course.

\section{Increased knowledge retention}

It has been established by numerous educational psychologists that the efficiency of long-term memory storage is a function of how well an individual archives information and can subsequently retrieve it; which are two distinct events from a cognitive perspective. Effective storage of information in long-term memory is facilitated by understanding, organizing, and integrating the new information with previously existing information. An increase in the methods used to store the information will improve the ease with which it can be retrieved in the future (Ormrod, 2004). In order to successfully complete a realworld project and satisfy external stakeholders, servicelearning projects require that the problem at hand be fully understood and organized into different segments for work assignments pertaining to the different members of a student team.

Additionally, the concepts being discussed in class must be joined to the new information gained during the project. The power of service-learning to interweave course material in with experientially derived concepts is showcased by Eyler \& Giles' research, "We have been continuously struck by the way in which the emotional power of service-learning helps students connect intellectually with what we were doing in the classroom (1999, p. 19). Other scholars investigating experiential learning have commented that it is engendered through the "adaptive modality of reflective observation," that is typically used at the summative stage of service-learning assessment, claiming that such a process is one in which "the very essence of knowledge is created" (Cooper, 1998, p. 51).

Learning at the highest levels of Bloom's taxonomy

The fact that service-learning occurs at the highest level of cognitive processing within the revised taxonomy of Bloom's hierarchy is a testament to its potential as a legitimate academic tool. The sixth and highest cognitive process in the new hierarchy, creativity, entails students fusing different knowledge together to form a "coherent, structured, and possibly original whole" (Ormrod, 2004, p. 316). Service-learning requires students not only to review course concepts for possible application, but necessitates that the requirements of project stakeholders, legal constraints, and outside research material all be fused together with course contents. Furthermore, since the problem being addressed by the service-learning project is unsolved, the student must utilize the amalgam of knowledge gained to create an original product to solve or mitigate the project's problem.

Figure 5 serves as an excellent illustration of servicelearning as a creative process. In a recent flight safety course at ERAU, a student team selected the reduction of near midair collisions in a dense air training environment as their service-learning project. After synthesizing the course guidance on midair collisions, investigating the aspects of the problem germane to the local airspace, and determining appropriate mitigation measures, the team created the poster shown in Figure 5. 


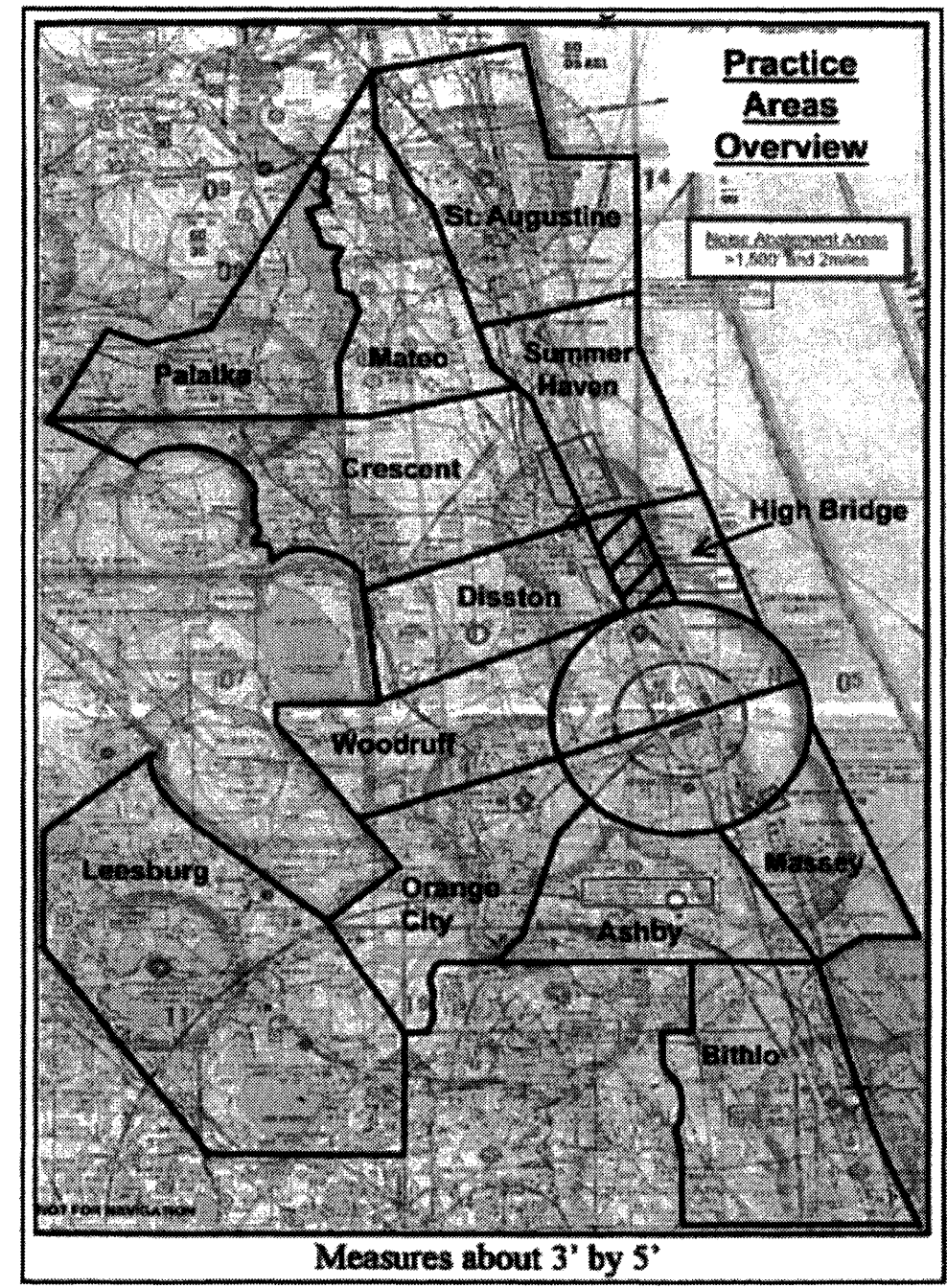

Figure 5. Midair collision avoidance chart posted at airports as a service-learning project.

The poster shows the boundaries of different training areas in the airspace near ERAU and also provides radio frequencies for monitoring the position and intentions of aircraft utilizing the areas for training. The poster was distributed to airports underlying the airspace depicted in an attempt to deconflict university aircraft from others training and transiting through the airspace.

Secondary learning achieved

As amazing as the primary learning achieved through service-learning can be, the educational value truly becomes apparent when one examines the other sources of learning that accompany all service-learning collaborative projects.
A second level of learning, which falls outside of the curricular purview, proves vitally important to the whole person concept espoused by most universities. Although the primary objective of service-learning is to deeply teach the course concepts through active learning techniques, the student also benefits significantly from being exposed to a real-world teamwork environment comprised of external deadlines, customers, and peer expectations.

Often times, it proves interesting to ask undergraduate students what the most important concept is that they have learned at the university. Many of them will be quick to reply with typical prefabricated remarks representative of 
advertisements produced by the institution to recruit them in the first place. Few students recognize that the most important function of academe, as far as the instructional mission is concerned, is to teach students how to learn. If life is viewed as a continuous learning event, then it seems that mastering the craft of learning will function as a catalyst for every event undertaken later on in life. Thus, learning how to learn is arguably the most critical of skills passed on through the hallowed halls of academe.

The small group interaction endemic to service-learning, as pictured in Figure 6, and the fact that real issues are being addressed, both motivate the student to learn in-depth about the issues and urges them to recognize how their academic learning has real relevance for problem solving in life. The nature of group work promotes self-understanding by comparing one's performance and mental mapping of a problem to those of other group members. The group's support induces trust and prompts priceless informal mutual feedback for each group member. The group setting provides an excellent way to learn how to learn. Not only do peers working together reinforce the concepts being discovered germane to the course, but also helps show each student alternate ways that a problem can be cognitively modeled (Tennant, 2004).

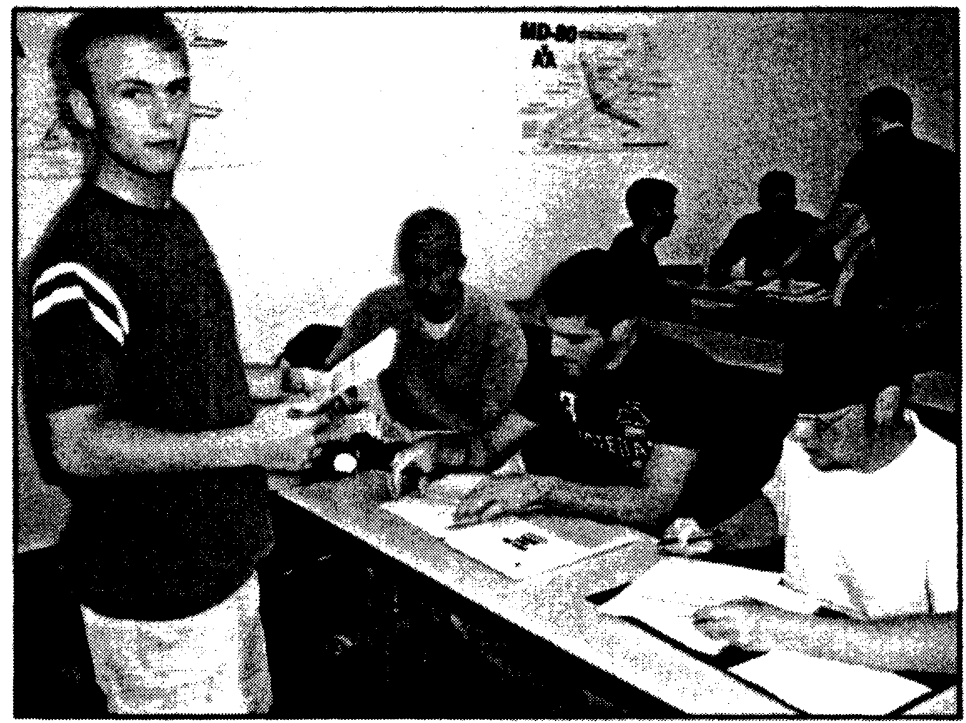

Figure 6. Secondary learning includes leadership, communication, and coordination skills, as shown by the student leader and team members in this picture of service-learning at ERAU. 
After a little more than a decade of serious implementation by some institutions, service-learning has proven itself as a respectable means for developing student soft skills. Some of the touted dividends include enhancing student capacity to learn by becoming aware of their own strength and weaknesses, and by observing similar qualities evident in their peers (Knowlton, 2003). The self-revelation of one's capabilities as a person is not to be dismissed as peripheral interstitial learning, since such knowledge proves central to all future learning and growth experiences. In a way, such secondary learning builds the foundation for successfully learning future concepts by creating a realistic framework of a student's capacity, identifying weak areas that deserve further attention.

Other secondary learning includes augmentation of written and oral communication skills stemming from the collaborative learning constructs of project work. Such improvements also tie in with a student's self-awareness of strong and weak intellectual areas (Knowlton, 2003). So often, people are not judged necessarily by their inherent knowledge, but by their capacity to accurately communicate concepts to others. Thus, an awareness of one's own communication prowess is a vital discovery that flows from group work and which is gained via feedback from one's peers and from those people who must be interacted with as part of the service-learning project.

Similarly, other equally important secondary benefits from service-learning in team settings include the awareness of how leadership and followership in real-world scenarios affect team dynamics, and how such dynamics impact the overall outcome of the project. All of the human dynamics within a team must reach harmony to produce a solution for the problem being faced in the service-learning project. "Problem-solving skills are a defining characteristic of an educated individual," concluded Knowlton, who stressed the importance of such skills by stating that, "without a focus on problem solving, professors are ignoring their responsibilities to help students journey toward the educated life" (2003, p. 11).

A summary of the secondary learning achieved through service-learning is best stated as students being provided with the opportunity to learn by using processes identical to those they will use during their careers after graduation and throughout life in their community. Supplementing their hitherto academic learning with the reality of life-based learning methods is a priceless skill to acquire while still within a university setting. Within academic classrooms, learning produced by assignments can best be labeled as being synthetic in that they focus on showing professors that students have mastered the material. In contrast, servicelearning produces work that transcends the academic boundaries and which is also evaluated by an external recipient with different expectations and evaluative criteria (Elyer \& Giles, 1999). Such a spectrum of assessment casts a novel light on student performance, from work accomplishment to how they communicate with others.

\section{Difficulties Encountered}

All the benefits stemming from service-learning notwithstanding, a few of the drawbacks must be mentioned in the name of fairness. As with any initiative pertaining to teaching, or any process in life, risk is always a close companion that must be recognized and managed. The greatest challenge to implementing service-learning has been to accurately measure its effectiveness, as opposed to the value derived from more orthodox teaching means. It also proves difficult to assess student performance on service-learning projects. As can be expected, servicelearning also suffers from the perils of faculty reluctance to embrace what is perceived by traditional scholars as a faddish initiative. On a more subtle level, although gains such as internalized loci of control and intrinsic motivation are touted, service-learning in itself is not necessarily conducive to raising student self-efficacy; a fact which can hinder some of the other benefits previously discussed.

\section{Self-efficacy not engendered}

The internal locus of control provided by servicelearning projects that proves so beneficial for achieving intrinsic motivation should not to be mistaken for attribution theory, where the past performance during an event is ascribed causation based on factors that were perceived as being within or outside of one's control. Self-efficacy is another related concept, introduced by Albert Bandura. Although troubled students may finally be convinced by advisors that future outcomes are within their control if certain actions are performed, a student may still not believe that they can actually perform the required actions to produce the outcomes (Ormrod, 2004). In other words, a student may believe that five more hours of studying a week can in fact raise test scores, but may not believe that they have the self-discipline to study that much more.

The application of self-efficacy principles to this issue is quite relevant. If a student has excelled in a service-learning course, it does not mean that her or his self-efficacy will transfer to a subsequent course. Self-efficacy is task specific. "When individuals believe they are competent, they gain in self-confidence and develop higher levels of persistence at and achievement of the task and develop higher goals for task achievement" (Bean \& Eaton, 2001, p. 77). Thus, professors using service-learning in a class must be conscious of possible low levels of student self-efficacy and should nurture each student's confidence in their ability to apply their skills to succeed in the process. With such a caveat in mind, it bears mentioning that a literature search produced no advice as to how such a process can be fostered by a professor in a service-learning environment.

\section{CAN SERVICE-LEARNING IMPROVE STUDENT PERSISTENCE?}

One of the unexpected benefits stemming from the 
incorporation of service-learning into mainstream academe is the purported link to student persistence. If such a link were proven to be true, it could potentially foretell the whole scale adoption of service-learning as a primary means for instruction across university curricula; particularly during the critical first two years of the college experience. Several researchers have worked assiduously to prove the causal relationship of service-learning to student persistence. When examining the reasons why first-year students are prone to return as sophomores, Keup determined that servicelearning processes taught students good academic practices that tended to promote persistence. Specifically, Keup's research proffered that, "service-learning facilitates the intention to re-enroll for a second year of college by its ability to enhance the quality and quantity of faculty interaction and to promote positive academic experiences for students in their adjustment to college during the first year" (2005, p. 82).

For those university administrators mindful of the need to manage student persistence, it proves fundamental to examine the processes within service-learning that may lead to an increase in student satisfaction with their place in academe with the concomitant result that they will continue with their studies until graduation.

\section{Interactionist Theory of Persistence}

The first theoretical link between service-learning and student persistence stems from the impact that social context creates on education. Tinto was one of the first to assert such a relationship by claiming that students who were more engaged in their institution, both academically and socially, were more prone to graduate (1993). Others have arrived at similar conclusions, such as "When students are socially and academically connected to their colleges, they are more likely to do well academically, graduate, and show evidence of personal and intellectual development" (Eyler \& Giles, 1999 , p. 48). When crafted in a team setting, servicelearning is precisely the type of activity that ties social interaction together with academic work. In addition to peer interaction, students participating in service-learning show increased discourse with faculty members and the community. The interaction with faculty is particularly important, because it breaks with merely engaging on theoretical concepts and allows professors and students to weigh different options for addressing real problems being faced during project work. The same processes occur when service-learning students deal with community stakeholders in their project. The increases in self-confidence and academic self-efficacy stemming from such interactions are fundamental for developing a personal value system that stresses academic excellence and which ultimately leads to improved persistence (Bean \& Eaton, 2001).

\section{Creation of loyalty towards the university}

Since typical service-learning projects showcase the student as a representative of the sponsoring university amongst the project's community stakeholders, the experience serves to build the identity of participating students with their school, thus increasing their loyalty to the school. Presumably, as the bond between the student and his or her university strengthens to the point that their status as a student becomes part of their self-identity, thoughts of dropping out or transferring become increasingly distant. A vivid testament of such a connection is provided by an interviewed student who remarked, "I didn't know why I was here at this university until I joined the two-year service learning program" (Elyer \& Giles, 1999, p. 48).

The process was also aptly described by Bean \& Eaton, who saw the psychological reaction to such interactions as a melding of personal and institutional values for academic excellence. "Integration leads to a more specific set of attitudes: institutional fit ('I fit in at this school') and institutional loyalty ("I feel I made the right choice to come here, being at this school is important to me')" (2001, p. 77). Positive effects of an Internalized Locus of Control

In addition to the interactionist effects and those of value melding, the previously identified tendency for servicelearning to create an internal locus of control produces benefits in persistence since it helps students realize they are in control of their academic performance. As an assigned service-learning project matures, students increasingly feel a sense of ownership, not just for their work, but for the community which it supports. Such empathy leads to an introspective analysis of each student's locus of control. Over time, students come to realize that their individual and group actions can actually engender change in life through the application of concepts taught through the course. "This belief is contrary to the external locus of control perspective that life's outcomes are only due to chance and luck. Students realize that by taking charge they can improve their lives" (Bean \& Eaton, 2001, p. 80).

The notion of being in control of societal change is akin to that of controlling the outcome of one's own academic success. The ability to apply the knowledge exposed in a course in real-world settings under the protection of an academic aegis is a unique opportunity for personal development. Fundamentally, such an opportunity leads directly to the recognition of how behaviors affect outcomes. Students learn to perceive how their actions can be adjusted in order to produce higher grades, which certainly pays off in terms of persistence in an academic program (Bean \& Eaton, 2001).

\section{SERVICE-LEARNING IN FLIGHT SAFETY COURSES}

After grasping the principles of problem-based learning in community settings, as exposed during several educational conferences, it was decided to experimentally apply service-learning in upper-class undergraduate flight safety courses at ERAU. Due to the ever-present need for safety husbandry in aviation and the multitude of flight 
training operations in the Daytona Beach area, it seemed logical to capitalize on service-learning as a way to cover the curricular objectives of the flight safety course. The natural starting point was to analyze the official accreditation-approved learning outcomes for the course to assess which ones were conducive to reinforcement through service-learning.

All five of the stated objectives in the course were deemed appropriate for exploration through service-learning projects. One objective in particular, "The student will be able to explain, demonstrate and program accident prevention activities which promote integrated, accident prevention actions," even seemed as though it was written with service-learning in mind. Once the applicability had been ascertained, it was decided to proceed with the redesign of the course delivery strategy by incorporating service-learning as an instructional vehicle.

Incorporating Service-Learning into an Existing Course

After two semesters of experimenting with servicelearning in numerous sections of flight safety courses, several salient conclusions have been reached and are offered here to help orchestrate similar efforts in other courses. A generalized six step process is recommended for planning and executing a service-learning curriculum in an aeronautical science course. The six steps commence with meticulous planning prior to the semester and finish with an assessment of how well the plan of instruction was executed.

\section{Step 1: instructional design}

The first and most important step for transforming a course into a service-learning experience is the meticulous construction of the course syllabus as a single-source document to answer student questions about the setup. The instructional design found to be optimal for use entailed front-loading the course with the requisite background information that fostered student success in service-learning. Specifically, concepts deemed to be necessary preparation for succeeding at real-world problem solving were placed first in the course schedule, which included covering topics such as philosophy of safety activism, accident and incident statistics, mishap report interpretation, data sources, and accident causation theory.

Due to the team nature of aviation and the benefits stemming from peer learning, the service-learning projects in the course were assigned to teams comprised of three to five students. It was determined that an absolute minimum of three students was required per team, due to the copious amount of work required on the projects. Since some students always drop courses after commencing the semester, it is advised that initial group assignments consist of no less than four students in order to create a one-student buffer in case of drops. As the course schedule is constructed, it is highly suggested that 15 to 30 minutes out of several initial class periods be dedicated to team time for the students to commence coordination of their projects. Student team leaders often comment on how challenging it is to coordinate meetings with team members outside of class periods due to the hectic schedule of most aeronautical science students. It thus proves imperative to provide time during scheduled class periods at the beginning of the semester for coordinating the fledgling efforts of the teams. When one considers how beneficial it is to have the professor available for consultation during the startup phase of the project, the use of class time for such meetings is deemed pivotal. Faculty should not see such time as a distraction from the core processes and material coverage in the course. Instead, it should be realized that team planning performed to accomplish service-learning projects is collaborative active learning at its finest and fosters the long-term memory storage of course concepts. As a minimum, a 15-minute team block should be provided before the end of the third class session, and then every three to four class periods henceforth.

Once the course schedule has been constructed, the syllabus can be written so that it carefully depicts the facets of the service-learning project and the grading criteria. The theme of the course was constructed to best represent the learning outcomes and to tie in with the service-learning that was to occur. The selected theme was, "Recognizing a developing accident chain and breaking it with courageous activism." The reference to courage entails the philosophical concept of moral courage that is so fundamental for taking ownership of accident mitigation measures during an accident incubation period.

As part of the planning process professors should decide how much project definition they will provide in the syllabus. Advantages and disadvantages abound for the amount of operational control students are empowered with. Intrinsic motivation is certainly fostered by allowing students to choose the topic they will pursue for their projects, but doing so may result in safety action that does not reinforce the core tenets of the course. Conversely, professors who delineate specific safety actions that they have previously identified as meriting attention in the community may channel student learning towards curricular objectives but may encounter a lack of student ownership over the solution finding process.

When considering the learning value that one team's work has on the other teams in the course, as exposed through presentations and interim team leader reports, it has been found that the optimal amount of operational control in projects lies somewhere between the previously stated extremes. The best approach experienced has been to provide the general topic to be explored and an illustrative historical accident as a reference, but to leave the actual safety action to be pursued up for debate by each student team. Figure 7 showcases the project topics assigned to different student teams in a flight safety course and the 
sample accident which was provided to illustrate the topic. Each service-learning project performed in the experimental flight safety courses consisted of four primary facets. The first phase was the research and coordination portion, which included investigating the nature of the assigned topic and the sample accident, plus coordinated with community stakeholders to determine what safety action should be taken. The second step in the project required actually executing the action plan to address the local manifestation of the assigned hazard. The third step required each student team to perform an oral presentation for the entire class describing the project topic, using the sample accident as an illustration of the need for safety action, and explaining the action taken in the local aviation community to address the hazard. The last step in the project was the production of a written report as documentation of the overall effort and to provide the opportunity for metacognitive reflection on the experience.

\begin{tabular}{|c|l|l|}
\hline TEAM \# & \multicolumn{1}{|c|}{ PROJECT TOPIC } & \multicolumn{1}{c|}{ SAMPLE ACCIDENT } \\
\hline 1 & Press-On-It-is (aka get-there-itis) & C-177B N35207, Cheyenne, WY, 1996 \\
\hline 2 & CFIT & Korean 801, Guam, 1997 \\
\hline 3 & Loss of Control on Landing & FedEx 14, KEWR, 1997 \\
\hline 4 & Pilot Fatigue & AMR 1420, KLIT, 1999 \\
\hline 5 & FOD & Concorde, Paris, 2000 \\
\hline 6 & Runway Incursions & MD-87 vs. Citation, Linate, Italy, 2001 \\
\hline 7 & Ramp Safety & US Airways Express 3340, KDCA, 2001 \\
\hline 8 & CRM \& Automation & Beech 400A N498CW, KBWI, 2002 \\
\hline 9 & Inflight Icing & Cirrus SR-22 N87HK, Childersburg, AL, 2006 \\
\hline
\end{tabular}

Figure 7. Flight safety service-learning project topics and sample accidents for each topic.

\section{Step 2: student preparation}

A strong, organized, and positively focused start of the service-learning project is imperative for students to perceive the undertaking as a desirable process. Prior to the first student team meeting during class time, safety activism should be introduced to the students as a noble and challenging life-saving endeavor that will require significant energy throughout the entire semester. Special mention should be made of natural quixotic tendencies to fix all that is wrong in aviation and how unrealistic such goals can be within the timeframe of a single academic semester.

After each student introduces themselves to the class during the first week of the course, it is suggested that the professor determine which students will comprise each team based on the biographic information provided during each student's introduction. Professors can ensure that each student group is intellectually and culturally diverse in order to orchestrate the work dynamics of each group.

Since the syllabus for service-learning courses is usually quite packed with all the details of project methodology and grading, it is suggested that a syllabus quiz be administered during the second week of the course to ensure that students have studied the contents of the syllabus and have become familiar with instructional expectations.
In order to curtail student straying away from the focus areas of the course curriculum, the syllabus can be designed to showcase the specific areas that should be addressed in the student presentations and papers. Doing so allows the other students in the course to maximize from the presentations they attend, while ensuring an adequate tie-in between theoretical concepts germane to the learning outcomes of the course and the experiential knowledge derived from performing the projects in the aviation community. During the experimental flight safety courses, the following six-step checklist was provided for students in the syllabus as a guide to what should be covered during the oral presentation and in the paper:

1. Description of the assigned safety hazard, including a detailed survey of its lethality and frequency.

2. Overview of the sample accident with special emphasis on evaluating the officially determined causes and comparing them to a student-performed root-cause-analysis of the accident.

3. Use of the sample accident to illustrate the different components of the assigned safety hazard. 
4. Description of the safety action taken by each team in the local community and an analysis of the extent to which the action will eliminate or mitigate the assigned hazard.

5. Discussion of three course concepts that have been applied during the service-learning project so as to successfully accomplish safety action in the community.

In order to promote individual accountability and encourage competition amongst teams, a record of the time each team had spent on their project was required and visibly posted on the course web site. The record was updated throughout the semester and was totalized at the end of the project. Figures 8 and 9 show portions of a sample record posted to the course web site by a service-learning team after the first few weeks in a course.

\begin{tabular}{|l|c|c|c|c|c|}
\hline & $911-917$ & $918-9: 24$ & $9: 25-10: 1$ & $10: 2-10: 8$ & $109-10: 15$ \\
\hline Hours of Work & 4.0 & 3.0 & 2.5 & 4.0 & 2.5 \\
\hline & & & & & \\
\cline { 2 - 6 } & $\begin{array}{l}\text { Read NTSB } \\
\text { Report, set up } \\
\text { spreadsheet, } \\
\text { researched } \\
\text { simbar accidents }\end{array}$ & $\begin{array}{l}\text { Changed } \\
\text { spreadsheet, re- } \\
\text { read section 2, } \\
\text { went over the } \\
\text { CVR }\end{array}$ & $\begin{array}{l}\text { Research/went } \\
\text { through accident } \\
\text { report }\end{array}$ & $\begin{array}{l}\text { Research/wrent } \\
\text { through accident } \\
\text { report, met with } \\
\text { team members. }\end{array}$ & $\begin{array}{l}\text { Researched } \\
\text { probable causes } \\
\text { in similar } \\
\text { accidents }\end{array}$ \\
\hline IWork Completed
\end{tabular}

Figure 8. Sample Microsoft Excel product provided by a team member as documentation of work performed on in the team on the assigned project during first few weeks of the course.

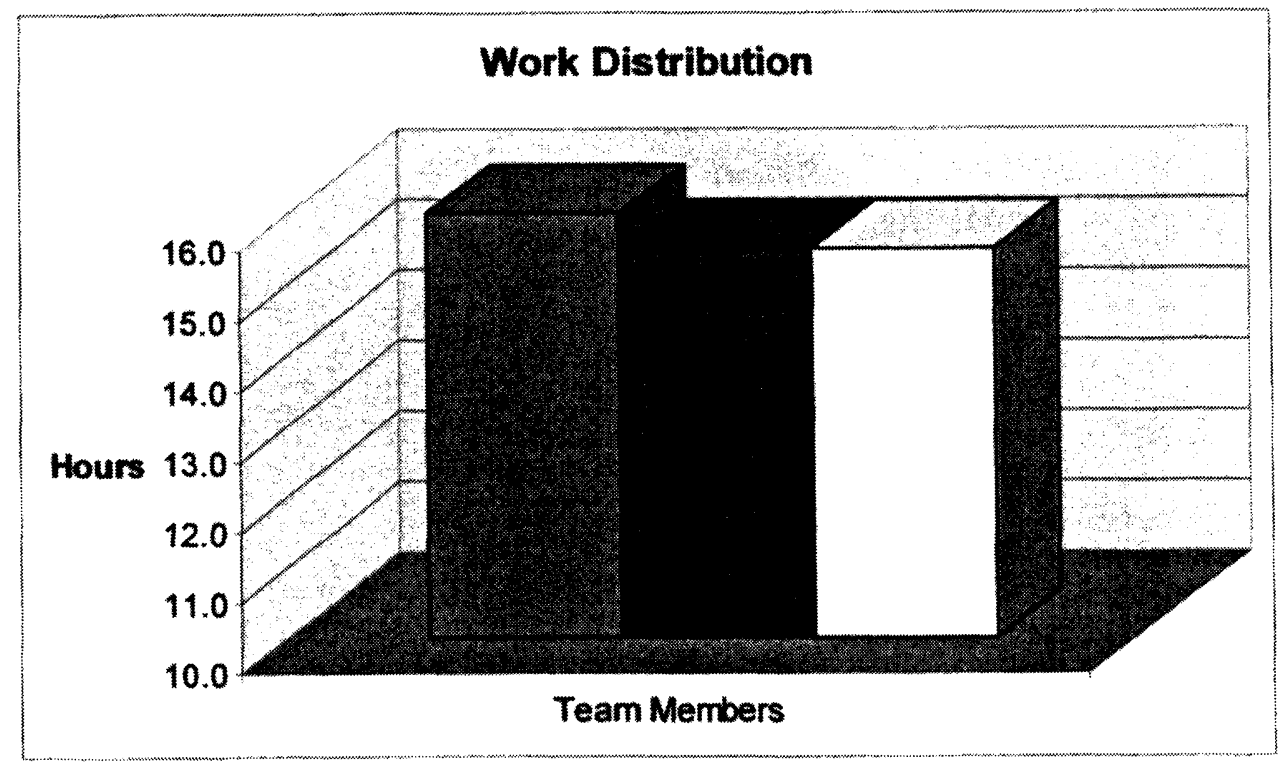

Figure 9. Sample graph provided by a service-learning team to document work performed on the assigned project during the first few weeks of the course (names removed from graph for privacy concerns). 


\section{Step 3: student action}

The crux of the instructional value of the assigned projects is undoubtedly the pursuit of the real-world safety efforts throughout the local community. Figure 10 illustrates how student teams in the past have worked in the local community to address large-scale safety hazards, such as midair collisions, decreased pilot performance due to dehydration, rental aircraft reliability, birdstrikes, and personnel propeller strikes.

\begin{tabular}{|l|l|}
\hline \multicolumn{1}{|c|}{ Aviation Hazard Identified for Project } & \multicolumn{1}{c|}{ Action Taken to Address Hazard } \\
\hline $\begin{array}{l}\text { Midair collision risk between aircraft performing } \\
\text { instrument approach training and skydiving operations at } \\
\text { nearby airport. }\end{array}$ & $\begin{array}{l}\text { Worked with government charting office and the FAA to } \\
\text { slightly offset the arc for a published instrument } \\
\text { approach procedure that was creating the airspace } \\
\text { conflict. }\end{array}$ \\
\hline $\begin{array}{l}\text { The hot weather in Florida creates a severe dehydration } \\
\text { risk for flight training students and instructors, which in } \\
\text { turn leads to an increase in pilot error. }\end{array}$ & $\begin{array}{l}\text { Dehydration short-course created for new university } \\
\text { pilots. Awareness campaign launched, including posters } \\
\text { for flight operations and free water bottles for pilots. }\end{array}$ \\
\hline $\begin{array}{l}\text { Pilots wishing to rent aircraft from local FBOs have no } \\
\text { way to compare the relative safety standards and } \\
\text { practices at FBOs. }\end{array}$ & $\begin{array}{l}\text { Created a standardized and user-friendly assessment } \\
\text { rubric to aid pilots in comparing safety cultures at } \\
\text { different FBOs in local area. }\end{array}$ \\
\hline $\begin{array}{l}\text { Can birdstrikes and the threat of personnel prop-strikes } \\
\text { on the ramp be simultaneously reduced by calling visual } \\
\text { attention to moving propellers? }\end{array}$ & $\begin{array}{l}\text { Collaborated with university maintenance department } \\
\text { and local propeller manufacturers to assess different } \\
\text { propeller paint schemes. Produces several proposals for } \\
\text { university aircraft propellers to make aircraft more } \\
\text { visible to birds and ramp personnel. }\end{array}$ \\
\hline
\end{tabular}

Figure 10. Sample service-learning project topics and actions taken for flight safety course.

A wide range of possible safety actions can be taken to address safety concerns in the local aviation community. The exact nature of the actions taken is best left up to the imagination and creativity of each service- learning team. Figures 11 through 14 serve as additional examples of myriad approaches to safety activism taken by service-learning students in the past. 


\section{DID YOU REMEMBER YOUR WATER???}

D iuretics (coffec, tca, soda) makes you urinate (wice what you consumed

E xcessive workouts before flying can hurt if you don't replace the water lost

II eadaches, dizziness, and especially fatigut can be caused by dehydration

Y ou shouldn't wait for symptoms- practice prevention!

D ry cockpit environment-only $5 \%$ humidity 20 minutes after takeoll- creales fluid loss

$\mathbf{R}$ amps and night lines can get extremely hot in the summer: WATCH OUT!

A lways hydratc, hydrate, hydrate!!!

T oo much sugar in sport drinks can precipitatc fatiguc even though they replace elcetrolytes.

I ncreased risk for kilney stones (common for dehydrated pilots)

$\mathbf{O}$ bserve the color of your urine. It's a good indicator.

$\mathrm{N}$ early two-thirds of your body weight is water ( $4 \%$ of your body weight lost in dehydration will cause a $10 \%$ decrease in overall performance!)

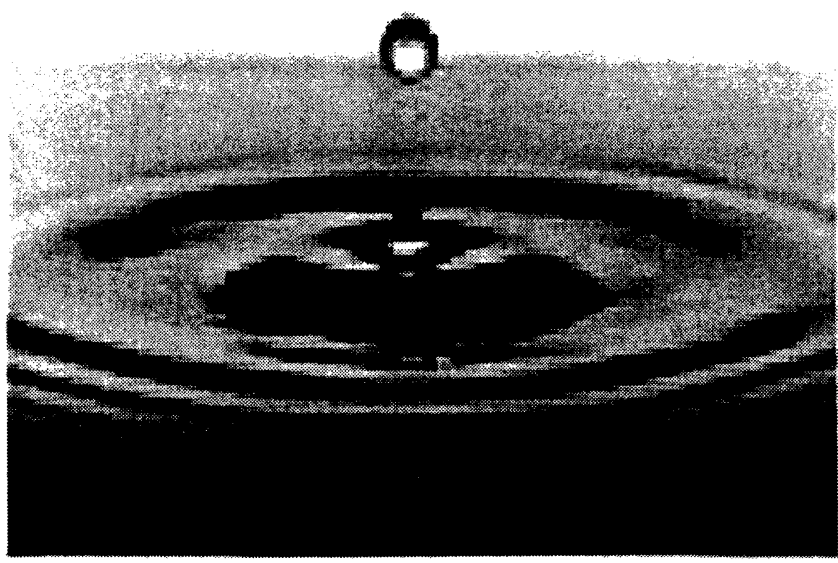

Figure 11. Handout distributed to flight training students and instructors in the aviation community as part of a dehydration awareness campaign in a service-learning project. 


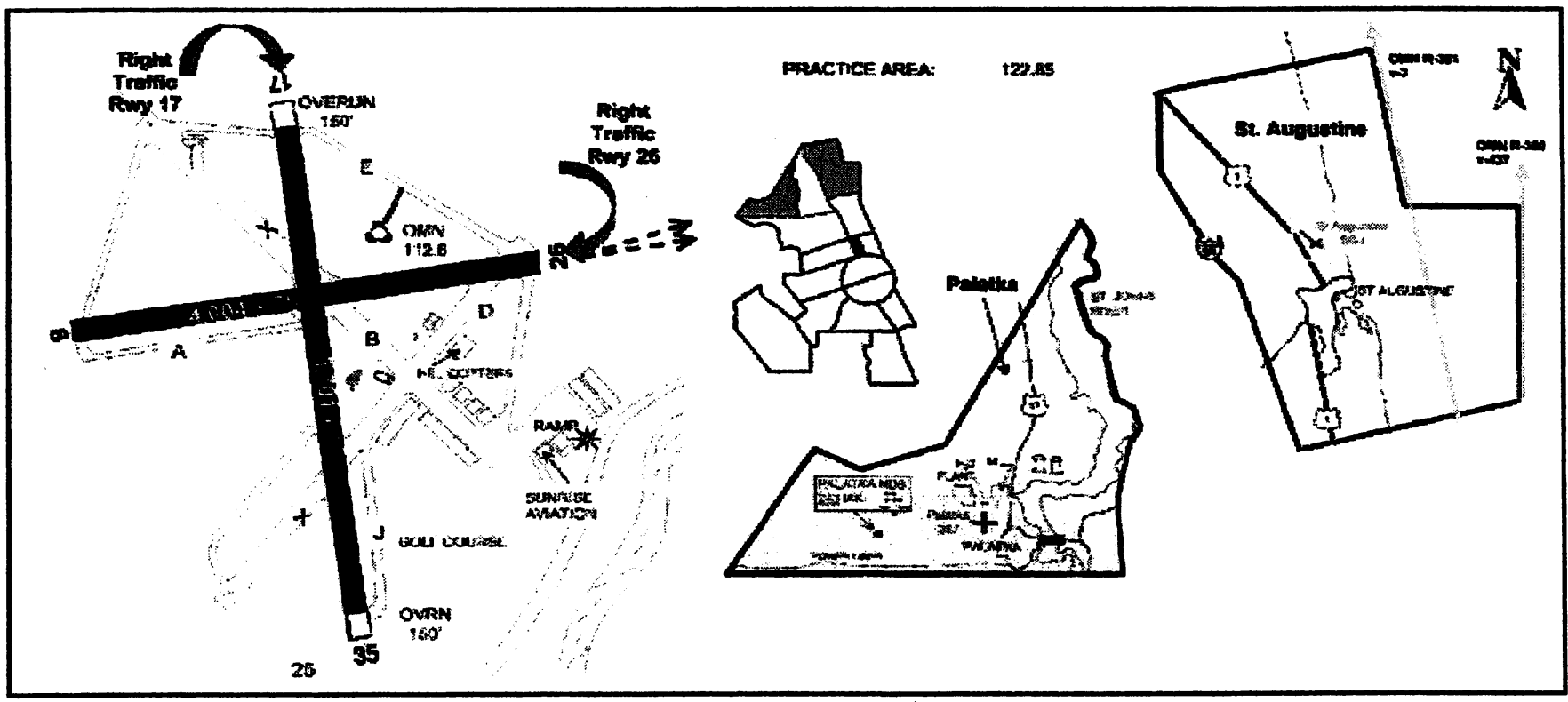

Figure 12. Portion of in-flight guide created and distributed to pilots in the local community as part of a midair collision reduction effort in a service-learning project.

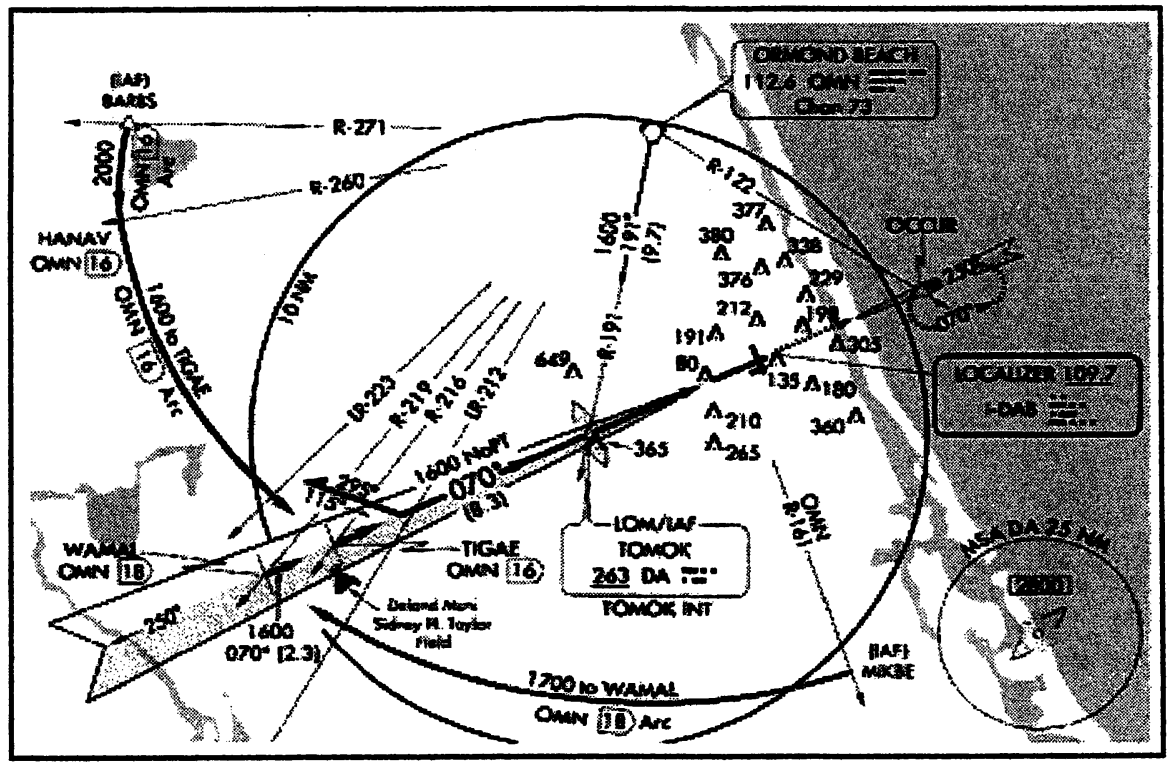

Figure 13. Depiction of a proposed alteration to the DME arc in an instrument approach procedure so as to reduce midair conflicts between instrument training sorties and skydivers. 


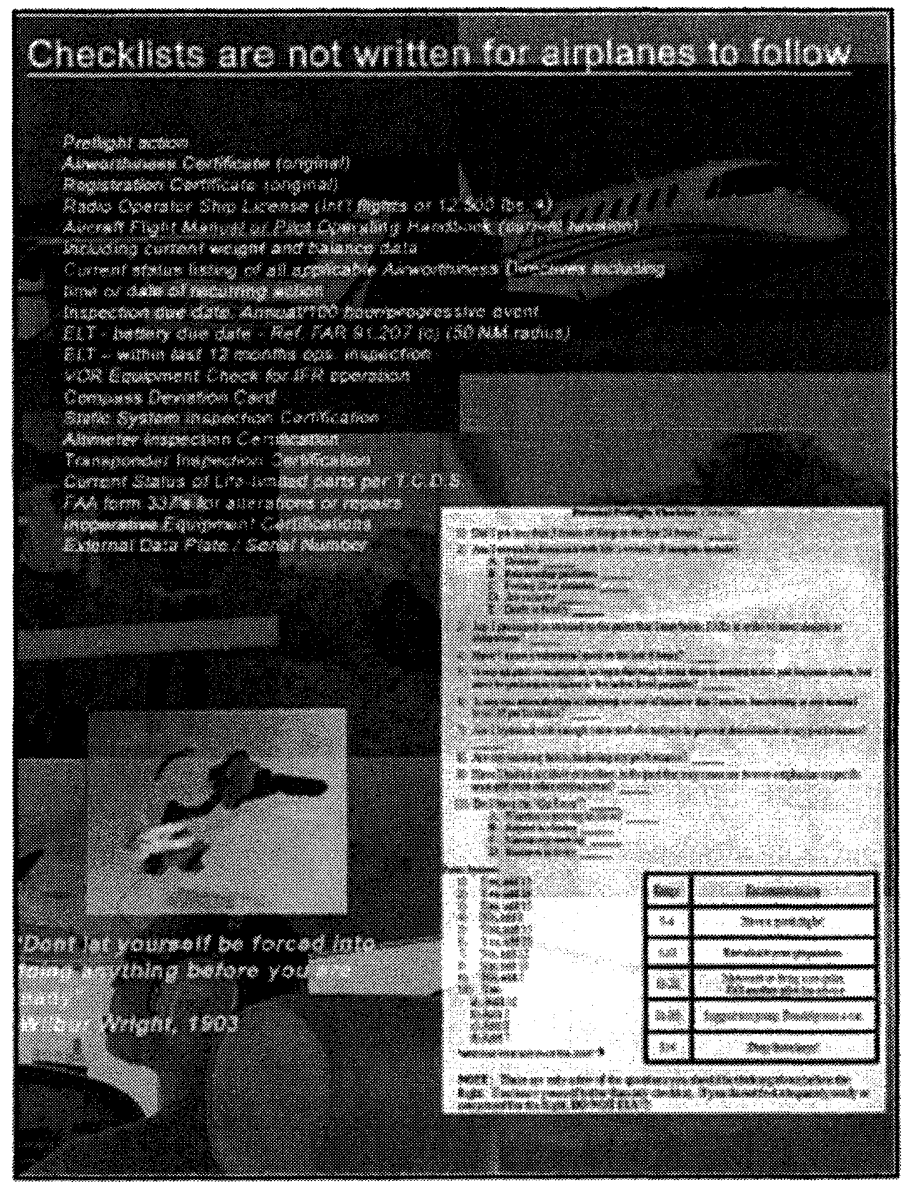

Figure 14. Poster created to educate pilots at local FBOs about the importance of conducting a personal airworthiness assessment prior to every flight.

\section{Step 4: student reflection}

As previously explained, the full learning potential of service-learning cannot be reached unless students are encouraged to reflect on the experience and on how it has changed them as practitioners of their discipline (Henley, 2003). Numerous venues are apt for such reflection, including personal testimonies provided during class presentations, homework assignments that are posted in the course web site for peers to examine, term papers that tie knowledge gained with metacognitive reflection on how it was obtained, and learning journals kept throughout the course of the project. Students often reflect on the sinuous path that their efforts have followed to successfully complete the action they intended at the start of the semester. Often times, recognition of the transmutation of intended actions and the forces behind the changes is of even more educational value than if the original goal had been adhered to without change. One of the most effective methods for fostering continuous reflection in a project is the use of learning journals.

Although not implemented during the service-learning experiments covered by this work, many educational psychologists tout the benefits of having students keep a learning journal in order to personalize, clarify, and internalize the lessons gleaned from tackling the assigned problem (Eyler \& Giles, 1999). In order for learning journals to be used correctly, professors must first train students how to write reflectively. As with any classroom 
assignment, requiring a student to fulfill a task in the absence of clear guidance is a recipe for confusion and concomitant frustration. Students must be taught how to properly reflect on the material presented in class, since merely encouraging metacognition without guidance may lead students to distort the material being learned by associating it with past experiences improperly (Hacker \& Dunlosky, 2003).

By having students make judgments about how the material presented in class is being applied in their servicelearning project, reflective journals promote critical thought by operating at the evaluative level of Bloom's cognitive process hierarchy. Journals spur reflective evaluation and the integration of new insights into existing interpretive frameworks, producing the necessary ingredients for critical thinking (Henley, 2003). Students use reflective journals as metacognitive tools by recording reactions to their learning of material covered in class and by evaluating how the new information changes their previously held beliefs. The process occurs because reflection on every week's learning provides a structured method for self-evaluation and facilitates the discovery of personal biases and unquestioned assumptions (Henley, 2003). The use of journals provides a perfect conduit for students to develop personal theories by constructing causal relationships amongst the concepts that are under study and seeing how those concepts are evidenced in their service-learning projects. Such reflection helps engender conceptual change by replacing previously held personal theories with new ones (Ormrod, 2004). The end result is that the consciousness of each student is elevated, thereby vastly expanding their perspective of the discipline being studied.

\section{Step 5: project assessment}

After some trial-and-error, the grading of the servicelearning projects was deemed best if divided into three assessment areas: the oral presentation, the written report, and the actual safety action taken during the project. All three areas of student assessment were contained on a single grading rubric, which is shown in Figure 15. The rubric was completed by the professor progressively as each portion of the project was evaluated at different points in the semester.

The oral presentation accounted for $20 \%$ of the course grade and was a team effort but contained individual graded elements. The team provided the overall setting for a successful presentation, but each student was held accountable for her or his portion of the presentation as well. A distinction was made on the grading rubric as to which items were calculated as a team and which were the graded for individual effort. The presentation was timed to induce efficient integration with other presentations during the restrictive class period. Points were subtracted from the presentation for timing that fell outside of the prescribed window.

The term paper comprised another $20 \%$ of the course grade. In different semesters during which the experimental introduction of service-learning in the course took place, the assigned paper switched between being an individual effort and a team product, with approximately equal advantages and disadvantages having been determined for each approach. Some students preferred sharing the workload of writing the paper with other members in a team, whereas other students voiced their desire to have retained complete operational control of the process by working individually. 


\section{AS 408 FLIGHT SAFETY PROJECT GRADING RUBRIC}

NAME: PROJECT:

DATE:

TEAM PROJECT ORAL PRESENTATION (one per team. 20 possible points)

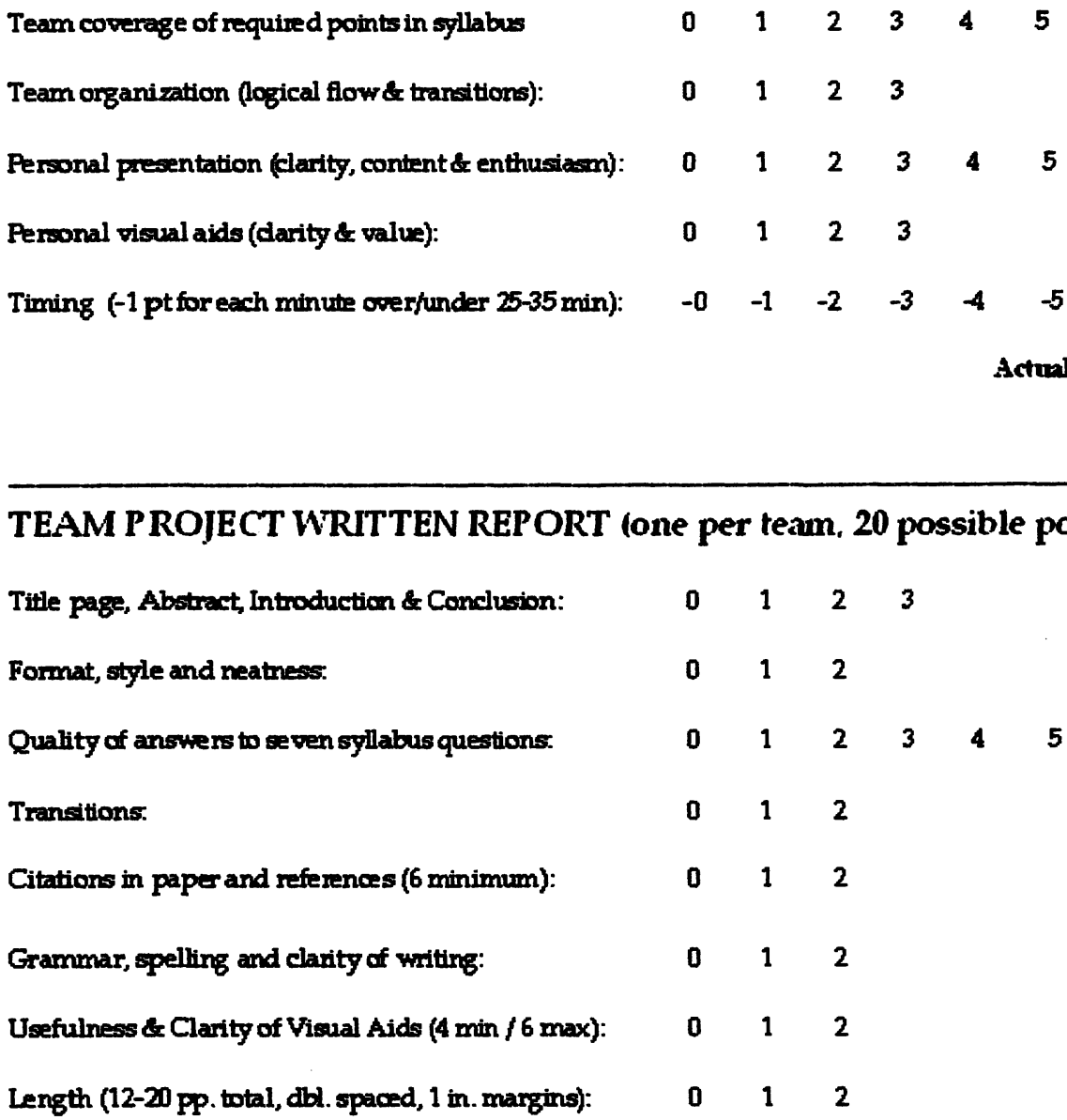

TEAM PROJECT ACTION(S) (15 possible points)

$\begin{array}{llllllll}\text { Effectiveness of product in addressing hazand: } & 0 & 1 & 2 & 3 & 4 & 5 \\ \text { Longevity and scope of actions' mitigation effects: } & 0 & 1 & 2 & 3 & 4 & 5 \\ \text { Completeness \& neatness of Team Project Wark Recond: } & 0 & 1 & 2 & 3 & 4 & 5\end{array}$

Pte.

Figure 15. The service-learning project student assessment rubric used in ERAU course encourages tying experiential knowledge to course concepts.

Lastly, the actual action taken in the aviation community was valued as $15 \%$ of the overall course grade and was 
assessed as a function of how effective it was at addressing the assigned safety hazard.

Step 6: instructional design assessment

In order to continuously improve the delivery of a service-learning course, and in much the same way as reflection should accompany delivery of any normal course, a few moments should be taken after the semester to assess the effectiveness of the service-learning experience. Such a determination may result from reviewing a combination of sources, with aims at improving the guidance for the service-learning projects in the syllabus for the next semester. Student feedback, obtained both formally and informally, can provide wonderful insights into how the initiative was received. Such feedback is important because it helps gauge how much buy-in for the process was obtained and, thus, helps portray the amount of intrinsic motivation that was generated. A comparison of student mastery of course concepts, by referencing final exam performance, may prove indicative of a change in the depth of student learning but is hard to distinguish from other learning effects engendered in the course and may be clouded by variations of student learning capacity and commitment from one semester to the next.

Although falling under the classification of anecdotal evidence, a collection of student comments culled from course evaluations and term papers are provided to illustrate student perceptions of the service-learning experience in flight safety courses. Some comments included, "This is awesome!" "Very challenging," "Tons of work," "I used what we learned in class," and quite telling in terms of implications for student persistence, "I wish we had done this in my previous three years."

Other more insightful and in-depth comments illustrate how receptive Millennial students were to the initiative and how personalized the learning became:

This project has been an amazing experience in that it has truly portrayed how important seeing an accident chain and breaking it with courageous activism really is. Working on a real project that involves human lives helps drive you to communicate with each other to get the job done better. Having a serious goal to work towards truly forces you to work together and help each other so that in the end no matter what happens you know that everything was done that could be done.

The linking of theory and practice became evident in the following student comment:

Projects such as these are vital to the learning process because they really give the participants a clear view of what it is like to have a mission that actually means something and will not only get you a grade at the end of it but will ultimately achieve something far greater than any grade you could get in a class."
The secondary learning obtained through the process is discussed in the following comment:

Along with having to work with three other people I have never worked with before in a group setting, I had to interact and eventually work with several professional staff members as well. I had to learn to use the information I received from them to help me put our product together.

The projects engendered a deep familiarity with the spirit of the course theme and provided an intense awareness of why promulgating aviation safety is so difficult, as shown through this quote:

During this project I have made a few mistakes, and learned a lot. At the beginning of the project, the theme of the course really didn't mean much to me, but now as I complete this project and I look back at the theme, I have realized that breaking an accident chain can be simple in thought and in reality quite difficult to achieve. It really does take 'courageous activism' to see something such as this project to the end. When working with the flight line...I learned that you sometimes need to give a little, to gain a lot somewhere more important.

Lastly, but perhaps of utmost importance, this student truly seems to have undertaken learning as a transformative process:

I believe that this project was a valuable opportunity to learn about aviation safety. But even on a deeper level, it changed my entire outlook on aviation as a whole. I feel like I now think like an activist, excited about helping people and inciting change.

With such a litany of positive feedback in mind, it proves quite compelling to recommend further experimentation with service-learning in flight safety. Furthermore, it seems only logical to investigate other courses in which similar projects can be undertaken within the aeronautical science curriculum.

With all the positivity from the experimental adoption of service-learning in the course abounding, it is important to mention the most salient negative aspects that were encountered by faculty during the semester. The same problems endemic to any student team effort was noticed; such as the occasionally recalcitrant leader and the undercontributing team member. Furthermore, the projects were deemed to be extremely time consuming by the students, who also commented that the long lead-times for producing change in the aviation community meant that teams had to start work on project actions almost immediately after the semester commenced, which is contrary to normal student expectations. Occasionally, the student projects encountered resistance from hidden agendas present in external collaborators. Such agendas actually countered intended safety actions, creating an excellent lesson for the students, who sometimes struggled to see the value of such a 
frustrating experience.

\section{CONCLUDING THOUGHTS}

Critics of higher education in the United States occasionally bemoan how new professors have rarely received formal schooling in how to teach. Supposedly, mastery of a discipline as during graduate school or through experience in the industry is sufficient to imbue a new faculty member with the skills required to excel as an architect of learning. One casualty of the established process is a perpetuation of ossified teaching orthodoxies that favor lecturing as a preferred instructional means, even though the passive learning that such a process engenders has been proven time after time as being highly ineffective. This leads to a prevalent mindset in academe that course objectives must be met by verbally transmitting information from faculty to student. An accompanying misnomer is that course objectives must be explicitly taught within the bounds of the classroom.

If the role of professors is assessed as being that of fostering learning versus broadcasting information, the entire focus of the educational effort becomes learnercentric. The proven and widely accepted practices of problem-based learning and experiential learning combine perfectly to foster active and pragmatic education via service-learning. Although challenges remain for the complete adoption of service-learning by academe, it has begun to transform the educational experience of millions of students around the nation; much to the utter delight of Millennial Generation students who relish group work and who strive to make a difference in life.

The final step in the full adoption of service-learning as a legitimate academic process is to encourage unknowing or recalcitrant administrators and faculty to embrace it as a learning catalyst and as a means for fostering student persistence measure. The timeline available for incorporating service-learning is unknown due to the uncertainty inherent in predicting the evolution of generational values. No one knows what value system the next generation of students will hold and if such a system will be conducive to service-learning. It is conceivable that service-learning, in its current manifestation, will reach a zenith of effectiveness in the next 10 to 20 years, only to face increasing disuse or transformation in response to changes in the values of the next generation of students.

Although not a panacea for all the problems afflicting higher education, service-learning offers an excellent and proven method for coupling academic concepts to pragmatic learning while fostering intrinsic motivation in Millennial students. Administrators, course monitors and professors throughout the scientific disciplines are urged to assess their curricula for opportunities to add service-learning wherever possible. If Mark Twain were alive today and could bear witness to the advances in service-learning, he would hopefully reconsider his allegation that schooling interferes with education and instead recast his view of higher education as a synergistic brew of theoretical and pragmatic learning which effectively prepares graduates for the rigors of life.t

Antonio I. Cortés, M.A.S., is an associate professor of aeronautical science at Embry-Riddle Aeronautical University in Daytona Beach, Florida. He teaches courses in safety, flight technique analysis, and airline operations. Prior to becoming a faculty member, Professor Cortés flew MD-80s for Midwest Airlines and was an aviation human factors consultant. He served in the U.S. Air Force as a C-21 check airman, C-141 aircraft commander, CRM facilitator, and flight safety director. His current doctoral studies in aeronautical science management with Northcentral University focus on the taxonomic analysis of airline pilot expectancy errors. 


\section{REFERENCES}

Barrows, H.S. (1988). The tutorial process. Springfield, IL: Southern Illinois University School of Medicine.

Barrows, H.S. (1996). Problem-based learning in medicine and beyond: A brief overview. In L. Wilkerson and W.H. Gijselaers (eds.), Bringing Problem-Based Learning to Higher Education: Theory and Practice. New Directions for Teaching and Learning, no. 68. San Francisco, CA: Jossey-Bass.

Bean, J., \& Eaton, S. B. (2001). The psychology underlying successful retention practices. The Journal of College Student Retention, 3, 1, 73.

Beckett, J., \& Grant, N. K. (2003). Guiding students toward solutions in field experiences. In D. S. Knowlton \& D. C. Sharp (Eds.), Problem-based learning in the information age (pp. 5-12). San Francisco: Joseey-Bass.

Brady, T., Stolzer, A., Muller, B., \& Schaum, D. (2001). A comparison of the learning styles of aviation and non-aviation college students. The Journal of Aviation/Aerospace Education and Research, 1, 1, 44-58.

Butin, D. W. (2006). The limits of service-learning in higher education. Review of Higher Education, 29, 4, 473. Retrieved October 22, 2006 from Proquest Education Database.

Champagne, N. (2006). Service-learning: its origin, evolution, and connection to health education. American Journal of Health Education, 37, 2, 97. Retrieved October 22, 2006, from Proquest Education Database.

Chen, X. (1998). Teaching undergraduates in U.S. postsecondary institutions: Fall 1998. Education Statistics Quarterly, 4, 3. Retrieved October 23, 2006, from http://nces.ed.gov/programs/quarterly/vol_4/4_3/4_5.asp

Conley, A. (2000). Service-learning. Enhancing the educational experience, improving communities, changing lives. Research \& Creative Activity, XXII, 3. Retrieved October 27, 2006, from http://www.indiana.edu/ rcapub/v22n3/p32.html

Cooper, D. D. (1998). Reading, writing, and reflection. In R. A. Rhoads \& J. P. F. Howard (Eds.), Academic service-learning: A pedagogy of action and reflection (pp. 3-10). San Francisco: Jossey-Bass.

Dibbert, D. S. (2006). Yours at carolina: Carolina's soul [Electronic version]. Carolina Alumni Review, 1, 112.

Evenbeck, S., \& Hamilton, S. (2006). From "my course" to "our program": Collective responsibility for first-year student success. Peer Review, 8, 3, 17-19. Retrieved October 22, 2006, from Proquest Education Database.

Eyler, J., \& Giles, D. E. Jr. (1999). Where's the learning in service-learning? San Francisco: Jossey-Bass.

Hacker, D.J., \& Dunlosky, J. (2003). Not all metacognition is created equal. In D.S. Knowlton \& D.C. Sharp (Eds.), Problembased learning in the information age:Vol. 95. New directions for teaching and learning (pp. 73-79). San Francisco: Jossey-Bass.

Haynes, T. (2006). 10 trends in youth culture. Leadership for student activities, 35, 1, 20-21. Retrieved October 22, 2006 from Proquest Education Database.

Henley, I. M.A. (2003). Aviation education and training. Adult learning principles and teaching strategies. Burlington, VT: Ashgate Publishing.

Howard, J. P. F. (1998). Academic service-learning: A counternormative pedagogy. In R. A. Rhoads \& J. P. F. Howard (Eds.), Academic service-learning: A pedagogy of action and reflection (pp. 21-29). San Francisco: Jossey-Bass.

Howe, N., \& Strauss, W. (2000). Millennials rising: The next great generation. New York: Random House Inc. 
Service Learning

Hughes, M. (2002). Moving from information transfer to knowledge creation [Electronic version]. Technical Communication, $49,3,275-285$.

Kaye, C. B. (2004). The complete guide to service-learning. Proven, practical ways to engage students in civic responsibility, academic curriculum, and social action. Minneapolis, MN: Free Spirit Publishing, Inc.

Keup, J. R. (2005). The impact of curricular interventions on intended second year re-enrollment [Electronic version]. Journal of College Student Retention, 7, 102, 61-89.

Knowlton, D. S. (2003). Preparing students for educated living: Virtues of problem-based learning across the higher education curriculum. In D. S. Knowlton \& D. C. Sharp (Eds.), Problem-based learning in the information age (pp. 5-12). San Francisco: Jossey-Bass.

Magolda, P., \& Kelsey, E. (2006). Millennials go to college: Implications for teaching and learning. Unpublished presentation, St. Norbert College Faculty Development Workshop, De Pere, WI.

Muthiah, R. N. (2003). Does service-learning make a difference? A comparison of educational activities and gains of undergraduate students who do and do not participate in a service-learning course. Unpublished doctoral dissertation, Indiana University.

Naughton, S. (2000). Understanding service learning. Retrieved October 27, 2006, from National Institute on Out-of-School Time at Wellesley College Center for Research on Women Web site: http://www.niost.org/publications/cns_4.pdf

Ormrod, J. E. (2004). Human learning (4 ${ }^{\text {th }}$ ed.). Upper Saddle River, NJ: Pearson Education, Inc.

Pietersen, C. (2002). Research as a learning experience: a phenomenological explication. The Qualitative Report, 7, 2. Retrieved October 22, 2006, from http://www.nova.edu/ssss/QR/QR7-2/pietersen.html.

Tennant, Mark (1997). Psychology \& adult learning ( $2^{\text {nd }}$ ed.). London: RoutledgeFalmer.

Theall, Michael (ed). (1990). Motivation from within: Approaches for encouraging faculty and students to excel. San Francisco, CA: Jossey-Bass Inc.

Tinto, V. (1993). Leaving college: Rethinking the causes and cures of student attrition. $2^{\text {nd }}$ Ed. Chicago: University of Chicago Press.

Titlebaum, P., Williamson, G., Daprano, C., Baer, J., \& Brahler, J. (2004). Annotated history of service-learning 1862-2002. Retrieved October 29, 2006, from http://www.servicelearning.org/filemanager/download/142/SL\%20Comp\%20Timeline\% 203-15-04_rev.pdf

Weigert, M. K. (1998). Academic service-learning: Its meaning and relevance. In R. A. Rhoads \& J. P. F. Howard (Eds.), Academic service-learning: A pedagogy of action and reflection (pp. 3-10). San Francisco: Jossey-Bass.

Wilder, S. (2005). What is service-learning? Retrieved October 28, 2006, from University of Georgia, Office of Service-Learning Web site: $h$ ttp://www.servicelearning.uga.edu/index.php?option=com_content\&task=view\&id=16\&Itemid=34

Woods, D. (1994). Problem-based learning: How to gain the most from PBL. Waterdown, Canada: Donald R. Woods. 